Int. J. Dev. Biol. 53: 835-850 (2009)

doi: $10.1387 / \mathrm{ijdb} .082615 \mathrm{sb}$

\title{
Zebrafish development and regeneration: new tools for biomedical research
}

\begin{abstract}
SEBASTIAAN A. BRITTIJN ${ }^{1}$, SUZANNE J. DUIVESTEIJN ${ }^{1}$, MOUNIA BELMAMOUNE2 ${ }^{2}$, LAURA F.M.BERTENS², WILBERT BITTER ${ }^{3}$, JOOST D. DE BRUIJN ${ }^{4,5}$, DANIELLE L. CHAMPAGNE ${ }^{6}$, EDWIN CUPPEN ${ }^{7}$, GERT FLIK ${ }^{8}$, CHRISTINA M. VANDENBROUCKE-GRAULS ${ }^{3}$, RICHARD A.J. JANSSEN ${ }^{9}$, ILSE M.L. DE JONG ${ }^{1}$, EDO RONALD DE KLOET ${ }^{6}$, ALEXANDER KROS ${ }^{10}$, ANNEMARIE H. MEIJER ${ }^{11}$, JURIAAN R. METZ ${ }^{8}$, ASTRID M. VAN DER SAR ${ }^{3}$, MARCEL J.M. SCHAAF 1,11 , STEFAN SCHULTE-MERKER ${ }^{7}$, HERMAN P. SPAINK ${ }^{11} 12$, PAUL P. TAK ${ }^{13}$, FONS J. VERBEEK ${ }^{2}$, MARGRIET J. VERVOORDELDONK ${ }^{14}$, FREEK J. VONK ${ }^{1}$, FRANS WITTE ${ }^{1}$, HUIPIN YUAN ${ }^{4}$ and MICHAEL K. RICHARDSON ${ }^{1}$

${ }^{1}$ Institute of Biology, Dept. Integrative Zoology, University of Leiden, The Netherlands, ${ }^{2}$ Leiden Institute for Advanced Computer Science, Leiden University, The Netherlands, ${ }^{3}$ Dept. Medical Microbiology and Infection Control, Vrije Universiteit Medisch Centrum (VUmc), Amsterdam, The Netherlands, ${ }^{4}$ Progentix BV, MB Bilthoven, The Netherlands, ${ }^{5}$ School of Engineering and Materials Science, Queen Mary University of London, U.K., ${ }^{6}$ Division of Medical Pharmacology, Leiden/Amsterdam Center for Drug Research (LACDR) and Leiden University Medical Center (LUMC), The Netherlands, ${ }^{7}$ Hubrecht Institute, Utrecht, The Netherlands, ${ }^{8}$ Department of Organismal Animal Physiology, Institute for Water and Wetland Research, Radboud University Nijmegen, The Netherlands, ${ }^{9}$ BioFocusDPI, Leiden, The Netherlands,

${ }^{10}$ Leiden Institute of Chemistry, Gorlaeus Laboratories, Leiden University, The Netherlands, ${ }^{11}$ Institute of Biology, Dept. Molecular Cell Biology, University of Leiden, The Netherlands, ${ }^{12}$ ZFscreens, Leiden, The Netherlands, ${ }^{13}$ Division of Clinical Immunology and Rheumatology, Academic Medical Center, University of Amsterdam, The Netherlands and ${ }^{14}$ Arthrogen BV, Amsterdam, The Netherlands
\end{abstract}

\begin{abstract}
Basic research in pattern formation is concerned with the generation of phenotypes and tissues. It can therefore lead to new tools for medical research. These include phenotypic screening assays, applications in tissue engineering, as well as general advances in biomedical knowledge. Our aim here is to discuss this emerging field with special reference to tools based on zebrafish developmental biology. We describe phenotypic screening assays being developed in our own and other labs. Our assays involve: (i) systemic or local administration of a test compound or drug to zebrafish in vivo; (ii) the subsequent detection or "readout" of a defined phenotypic change. A positive readout may result from binding of the test compound to a molecular target involved in a developmental pathway. We present preliminary data on assays for compounds that modulate skeletal patterning, bone turnover, immune responses, inflammation and early-life stress. The assays use live zebrafish embryos and larvae as well as adult fish undergoing caudal fin regeneration. We describe proof-of-concept studies on the localised targeting of compounds into regeneration blastemas using microcarriers. Zebrafish are cheaper to maintain than rodents, produce large numbers of transparent eggs, and some zebrafish assays could be scaled-up into medium and high throughput screens. However, advances in automation and imaging are required. Zebrafish cannot replace mammalian models in the drug development pipeline. Nevertheless, they can provide a cost-effective bridge between cell-based assays and mammalian whole-organism models.
\end{abstract}

KEY WORDS: Danio rerio, zebrafish, high-throughput screening, high-content screening

This article is part of a special journal issue on "Pattern Formation". In this context, it seems appropriate to ask: 'what benefits to society can come from research into pattern formation?' The answer depends on how "pattern formation" is defined. For our purposes, it includes developmental mechanisms that generate specific phenotypes (i.e. reproducible patterns of cell behaviour or tissue organisation) during development or regeneration. This definition of pattern formation identifies a number of areas of research that are of potential benefit to society.

One is the field of human congenital malformations (the pres-

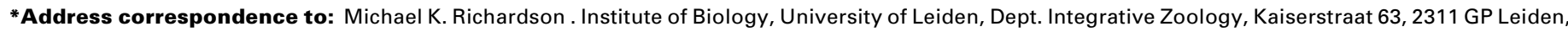
the Netherlands. e-mail: m.k.richardson@biology.leidenuniv.nl

Supplementary Material for this paper (additional Results, Discussion and Methods) is available at: http://dx.doi.org/10.1387/ijdb.082615sb

Published online: 23 June 2009

ISSN: Online 1696-3547, Print 0214-6282

(C) 2009 UBC Press

Printed in Spain 
ence at birth of anatomical abnormalities). Good examples are human malformations of fingers and toes, some cases of which are linked to mutations in the Hox family of developmental patterning genes (Akarsu et al., 1996; Goodman et al., 1997; Goodman, 2002). Teratology - the study of agents that cause congenital malformations - can be seen as applied pattern formation research. Tissue engineering, a medical research discipline that aims to create replacement tissues for patients who have suffered injury or surgical removal of tissues, is another area where knowledge of pattern formation can be applied. To date, the commonest approach to tissue engineering is to culture autologous cells on a synthetic template (Silva and Mooney, 2004). In the future, however, it may be possible to promote pattern formation by these cells so that they generate selforganised tissues or structures (Brockes and Kumar, 2005; Reddi, 2000).

Here, we discuss how new medical research tools are emerging from zebrafish developmental biology research. We describe a range of zebrafish-based phenotypic assays for drug screening and tissue engineering. Preliminary data and proof-of-concept studies from our own labs are also presented.

\section{Zebrafish developmental models: pros and cons}

The zebrafish (Danio rerio) is a tropical, freshwater teleost fish related to the carp. It is widely used for fundamental research into pattern formation, developmental mechanisms and disease processes. Several technical and practical considerations make zebrafish useful in such research (reviewed by Dahm and Geisler, 2006; Kari et al., 2007). They are cheap to breed, with pairs producing 100 - 400 eggs per week throughout the year (Dahm and Geisler, 2006). In contrast to mammalian model species such as rodents, zebrafish develop outside the mother. This means that they can be raised in Petri dishes or even multi-well plates filled with water. Morpholino knockdowns (www.genetools.com) can be performed by injecting the yolk sac of early cleavages stage embryos, and the tissues of the developing embryo are transparent or translucent, making it possible to perform live imaging studies. Their genome is available as a preliminary assembly ${ }^{1}$, and thousands of mutant lines have been generated (Driever et al., 1996; Haffter et al., 1996). Robotics are being developed to allow medium- and high-throughput screening (e.g. Wang et al., 2007). Finally, many human disease-related genes have orthologues in the zebrafish ${ }^{2}$. These features of the zebrafish model system make it useful for drug screening and other types of applied research (Berghmans et al., 2005; Kari et al., 2007; Lieschke and Currie, 2007; Rubinstein, 2003; Stern and Zon, 2003; Zon and Peterson, 2005).

Humans and zebrafish share a common ancestor that lived around 400 million years ago (Dahm and Geisler, 2006). This has led to obvious divergence in form and function. For example, zebrafish lack synovial joints, hair follicles, cardiac septation, lungs, external genitalia, mammary glands, limbs, bone marrow, and other features possessed by humans. Furthermore, zebrafish are cold-blooded; their adults and embryos are typically raised at $28.5^{\circ} \mathrm{C}$. This means that mammalian cells, transplanted into a zebrafish host, are not at their normal physiological temperature - although they can survive, migrate and proliferate in the zebrafish host (e.g. Haldi et al., 2006). A further consideration is that teleost fish, including the zebrafish, have undergone an extra round of partial genome duplication compared to tetrapods, and so $20 \%$ of mammalian genes have two orthologues in zebrafish (Dahm and Geisler, 2006). Such gene duplications may well be associated with changes in function of at least one member of the gene pair (Prince and Pickett, 2002).

These considerations show that models based on zebrafish developmental processes are useful only in specific contexts (a fact that applies to all animal models of development and disease; see Bier and McGinnis, 2003). These contexts, as we shall discuss below, include high-throughput screening, and the testing of drugs that act at early developmental stages (i.e. stages when rodent embryos are relatively inaccessible in utero). Zebrafish cannot replace mammalian models in the drug development pipeline - particularly at later stages when the regulatory authorities demand studies in mammalians and clinical trials. Furthermore, zebrafish are not the only options for high throughput drug screening; mammalian cell-based assays are extremely costeffective. However, cell-based assays can not be used for studying organism-level features of diseases, or complex biological phenomena. A particularly severe test of cell culture systems is provided by diseases such as depression or anxiety which demand a whole animal model, at least for phenotype-based assays. Zebrafish developmental models can therefore function as a useful bridge between cell-based models on the one hand, and rodent whole-organism models on the other (Fig. 1).

\section{Skeletal patterning and regeneration}

The zebrafish shares many key features of bone formation with humans and other animals (Mari-Beffa et al., 2007; Renn et al., 2006). Dermal bone is found in the fin rays, while endochondral bone is present in the supporting skeleton at the fin base (Bird and Mabee, 2003; Grandel and Schulte-Merker, 1998). Staining with the fluorescent chromophore Calcein can provide a simple readout $^{3}$ for bone assays in the zebrafish. It stains calcified tissue in live fish, including the head skeleton at 5 days post-fertilisation (dpf), the axial skeleton at 7dpf and caudal fin rays at day 12 . Calcein staining is abolished locally in the zebrafish skeleton by ectopic expression of BMP2 (Du et al., 2001).

Possibilities for the use of cheaper, non-animal research models in the field of bone and joint disease are limited. For mineralised bone, good cell lines are not available, and work with patients' tissue is limited by the availability of samples. Special cell culture systems can be used to some extent (e.g. the micromass culture of cells to study cartilage development (Daniels et al., 1996). But studying, for example, the destruction of articular cartilage during an inflammatory response is not always easy to model in vitro, given the complexity of cellular interactions in-

\footnotetext{
${ }^{1}$ At the time of writing (January, 2008), assembly version 7 (Zv7) was available on the website http://www.ensembl.org

2 See, for example, the human-zebrafish disease gene library at http://zenemark3.znomics.com/cgi-bin/diseaselib.pl

${ }^{3}$ In this article, the term "readout" refers to the endpoint of a phenotypic character which is recorded at the end of the assay. The state of that character is used to determine whether the test compound has a specific biological effect.
} 


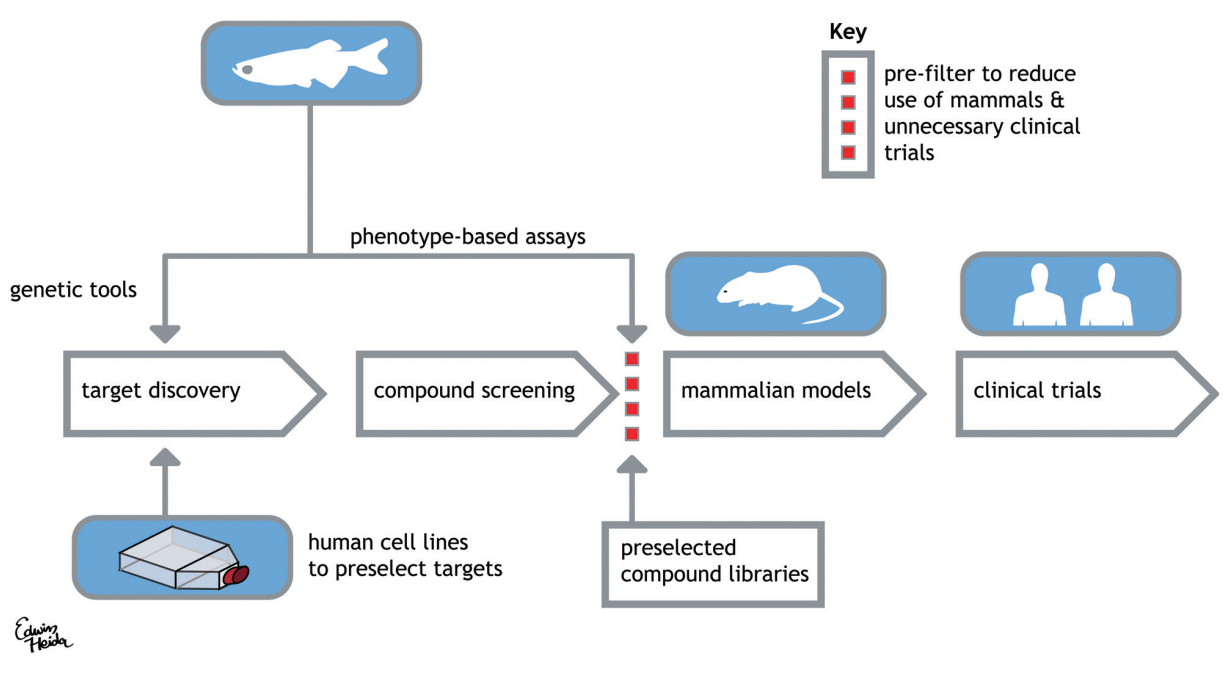

Fig. 1. A potential drug development pipeline showing incorporation of novel approaches using cell-based and zebrafish assays into target discovery and zebrafish assays into compound screening. to $20 \%$ of the total body calcium pool may reside. Fish scales are dermal bone plates, formed by scleroblasts - osteoblast-like cells that form an armour for protection. Scales also provide the fish with an important and readily exchangeable calcium and phosphate buffer compartment for whole body calcium and phosphate homeostasis (Bereiter-Hahn and Zylberberg, 1993; Flik et al., 1986). Scalar calcium may, for instance, be recruited during periods of increased calcium demand such as during oogenesis/ vitellogenesis or when environmental sources for calcium are low (e.g. in very soft water). Both bone formation (mediated by scleroblasts) as well as bone degradation (mediated by scleroblasts or multinuclear osteoclasts) is observed in scales in the intact fish. Thus, morphologically and physiologically, fish scales volved. The zebrafish raises the possibility of replacing mammalian testing of osteogenic compounds on mammals. Previously, mammals have been used for the implantation of osteogenic drugs and surgical matrices, and then killed for histological analysis. This work typically uses goats, dogs, rabbits or rodents (Dai et al., 2005; Habibovic et al., 2006; Yamamoto et al., 2006; Yuan et al., 2006b). And while these tests are scientifically valuable, they are also expensive and raise ethical and welfare issues.

As mentioned above, synovial joints are lacking in the zebrafish, and so its uses as a model for human joint disease are limited. Furthermore, endochondral bone at the base of the fin does not regenerate. Nonetheless, other processes central to many bone and joint diseases, namely inflammatory responses, bone formation and bone turnover, can be modelled in fish.

\section{Skeletal regeneration and osteogenesis models}

Adult zebrafish are capable of regenerating multiple structures including fins, optic nerve, scales, heart, and spinal cord (Becker etal., 1997; Bereiter-Hahn and Zylberberg, 1993; Bernhardt etal., 1996; Poss et al., 2002); for reviews see (Akimenko et al., 2003; Nakatani et al., 2007; Poss et al., 2003).

The caudal fin regeneration system is particularly well-studied. When the caudal fin of an adult fish is amputated, the stump is covered by a specialized wound epidermis within one day. Beneath the wound epidermis undifferentiated mesenchymal progenitor cells start to accumulate probably through dedifferentiation processes (Akimenko et al., 2003; Akimenko et al., 1995; Poss et al., 2003). These cells will make up the blastema. Connective tissue cells, the main cell population of the fin, are excellent candidates for blastema formation (Akimenko et al., 2003). It has also been shown that intra-ray cells located up to seven segments proximal to the wound can migrate along the ray and contribute to the blastema (Poleo et al., 2001).

Another osteogenesis model - the regenerating fish scale is developed mainly in teleosts other than zebrafish. Scales offer a unique and versatile model for studying osteogenesis. They make up a significant bone compartment in scaled fish, where up resemble mammalian bone, with scleroblasts and osteoclasts as the cellular units controlling bone mass.

When a scale is plucked from the skin, osteoblasts and osteoclasts remain attached to the scale. The scale bone plate and associated cells are easily cultured, providing a bone cell culture with all cells attached to a natural bone matrix and directly exposed to the medium of choice. Further advantages are the possibilities to manipulate bone cell kinetics (by adapting the ectothermic fish to different water temperatures), or manipulating its growth rate (by altered feeding levels).

Classical markers for osteoblast activity (e.g. calcitriol-sensitive alkaline phosphatase; ALP), and osteoclast activity (e.g. tartrate-resistant acid phosphatase; TRAP), can be biochemically or immunohistochemically assessed. Our present studies focus on the molecular markers for bone formation and their endocrine control systems (e.g. PTHrP and calcitriol and their receptors; (Abbink and Flik, 2007; Lock et al., 2007), which are remarkably conserved at the nucleotide and protein levels in most fish, including cyprinid species such as zebrafish and common carp. Most genes for bone-regulatory (e.g. BMPs) and bone matrix proteins (collagen type I, osteonectin) appear extremely wellconserved among vertebrates.

Importantly, in the emptied scale pocket that results from removal of a scale, mesenchymal progenitor cells, called scale pocket lining cells, reorganise to rapidly form a same-sized, new scale. This takes one to three weeks, depending on the ambient temperature of the fish (carp and, to a lesser extent zebrafish, are eurytherm fishes, and this allows for experimental control over bone formation kinetics). We will focus on both zebrafish and carp in future studies, but use the carp, with its large scales, for model development. The osteogenetic process of a regenerating scale is comparable to appositional or mammalian membranous bone formation (Yoshikubo et al., 2005).

Development and regeneration of scales appear basically similar in terms of morphology, but differ as a result of the rate of bone formation and the relative size of appositional bone formation zones (Fig. 2). As a result, any designated region of the scale can be dissected to obtain cells that are progenitor-like (early 

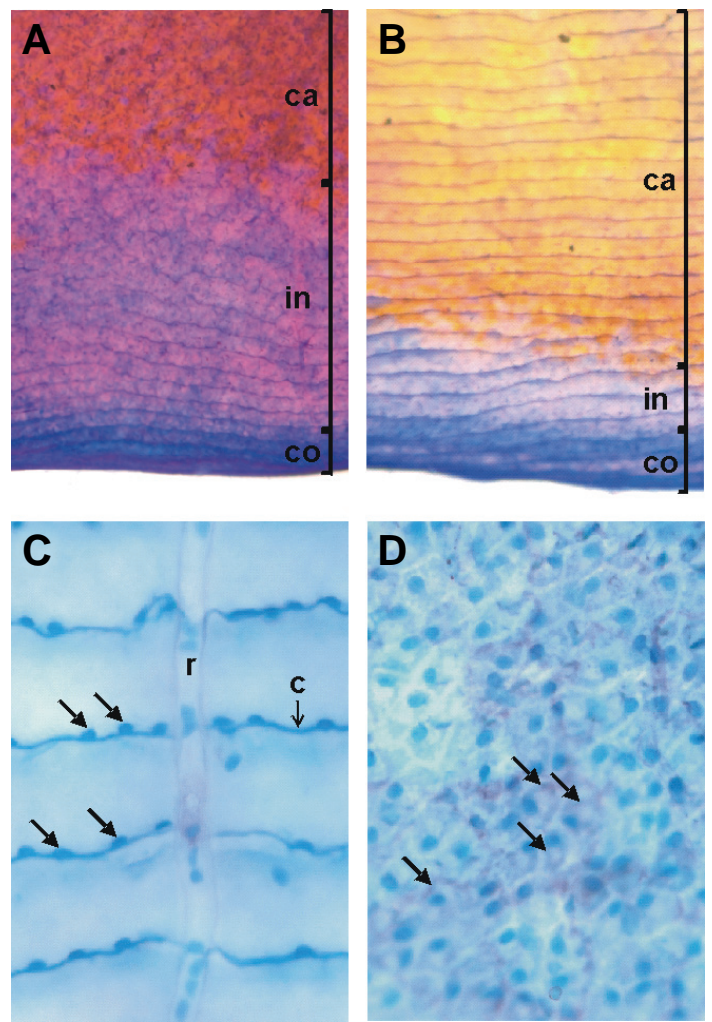

Fig. 2. Overview of basic morphology of scale regeneration in the common carp, Cyprinus carpio. $(A, B)$ Low magnification images of sections of a 16-days regenerated (A) and the ontogenetic (B) scale stained by trichrome staining. Differential activities in the calcified (ca) zones and in the zones of calcification initiation (in) are observed. The area of collagen production (co) is comparable in size. (C,D) High magnification images of the calcification initiation zone of a 16-days regenerating scale. Scales were fixed in ice-cold acetone; sites of ALP

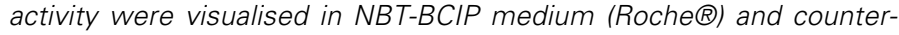
staining was performed with Alcian Blue to label cell nuclei. (C) Episquamal side of scale showing a radius ( $r$ ) and circuli (c). Arrows indicate ALPnegative cells, with osteocytic characteristics. (D) The same scale and position as in $C$, but in a lower focus plane thus showing the hyposquamal side. There is a clear abundance of ALP enzymic activity, predominantly at the periphery of the bone-matrix forming scleroblasts (arrows) indicative of release of ALP to the extracellular matrix.

regeneration, or outer edges of regenerating scales), merely active in collagen secretion, or more so in the process of ALP secretion at the start of mineralisation. Importantly, ALP-positive scleroblasts are found predominantly on the inner, 'hyposquamal', side of a scale (Fig. 2) and these cells can easily and specifically be collected, at determined times of scale regeneration. Cells on the external, episquamal, side express less ALP, are less active and remind more so of mammalian osteocytes. We have successfully used the scalar bone plate, freed from its original cells, as substrate for the culture of mammalian bone cells, and we observed remarkable differences in osteoclastic activity when cells were seeded on the external, fully mineralized face of the scale compared to the hyposquamal side that consists of less mineralized bone matrix (G. Flik unpublished observations).

\section{Target discovery and skeletal disorders}

The central problem in developing new therapeutics for skel- etal diseases is to obtain a better understanding of the molecular players and biochemical pathways that contribute to the function of a particular organ system. While it is extremely difficult to mimic the behaviour of any organ in cell or tissue culture, this is particularly true for mineralised tissues, as good cell lines are not available, and work with primary (or patient) material is limited by reproducibility issues and the availability of samples. Pharmaceutical companies therefore usually have to wait years before they can test possible lead compounds (candidate therapeutics) in a whole-animal system. Ideally, one would like to have available a large number of vertebrate animal lines, each deficient in one specific gene or protein, in order to test gene function in any given disease context.

For example, if there was a library of mutant mice deficient in all kinases, one could efficiently test whether the lack of a particular kinase has therapeutic or protective effects in a given indication area. Such libraries do not exist, and would be very expensive to create in mice. Alternatively, one would like to perform forward genetic screens in a vertebrate model system, and use read-outs which are relevant for a particular indication area. This approach has the advantage that an 'in vivo' validation of gene function is performed at the onset of the project, making ensuing compound screens for genes identified in a forward screen much more meaningful.

Bone formation, and the maintenance of bone structure, is the result of a balanced interplay between osteoblasts (cells that produce mineralized bony matrix) and osteoclasts (cells that resorb and remodel bone). This finely tuned balance is established early in mammalian embryogenesis, and must be maintained throughout life for proper bone function. The zebrafish, as a vertebrate, provides an excellent model for bone formation, as organogenesis can be easily monitored due to the rapid development of zebrafish embryos outside the mother. Furthermore, reverse and forward genetic screens are possible. To date, zebrafish and medaka have not been fully appreciated as systems which can make a real contribution to the field of osteogenesis and osteoblast function. None the less, genes important in mammalian osteogenesis and skeletal patterning have zebrafish orthologues whose expression patterns suggest functional conservation (Crotwell and Mabee, 2007; Mari-Beffa et al., 2007).

Using histological staining as a read-out for bone formation, a genome-wide, large scale forward genetic screen has been carried out in zebrafish. This led to the identification of 101 mutants with defects in bone formation (Fig. 3). Since the screen was performed at a stage of development when osteoblasts - but not osteoclasts - are present in the zebrafish larva (Trowe and Schulte-Merker, unpublished data), all defects in bone formation are likely due to defective osteoblast function or defective calcification. Mutants that showed additional defects such as pericardial oedema, cartilage malformations or brain necrosis were not kept in order to specifically retain only those mutants that are likely to be largely osteoblast-specific. Due to the scale of the genetic screen carried out, a considerable fraction of the genes essential for osteoblast function has probably been identified. Whether the screen has achieved saturation will have to be determined by complementation assays and by determining the average allele frequency (Haffter et al., 1996).

This set of mutants provides a unique set of tools to identify genes not previously implicated in osteoblast function, and thereby 
opens possible avenues to new therapies. Forward genetics are unbiased by definition, and offer the chance to identify gene function previously not appreciated to be involved in a particular process (Amsterdam and Hopkins, 2006; Driever et al., 1996; Haffter et al., 1996). The mutated gene responsible for the phenotype then needs to be identified, but the upside of this sometimes laborious process is that the identified gene already has been shown to have an essential role in the biological process of interest.

In terms of identifying new gene functions relevant for pharmaceutical research, mutants that show over-ossification might be most interesting (Fig. 3). These phenotypes, ranging from comparatively mild over-ossification to gross examples showing a premature onset of embryonic ossification in all locations, and massive nodes of excessive bone mass in the adult skeleton, are most likely caused by mutations in negative regulators of osteogenesis, as gain-of-function mutations are rare in zebrafish. These mutants can be crossed out to establish mapping crosses, and the genomic location of the mutated gene can then be identified. This allows to cross-reference the genomic position of the mutant gene with the few genes that are known to cause, in mice, over-ossification. This approach prevents following up cases where the respective mutant maps to, for example, a region that contains the zebrafish orthologue of SOST(van Bezooijen et al., 2004) or HDAC4 (Vega et al., 2004), i.e. genes that, when mutated in mammals, result in over-ossification. Mutant zebrafish genes can be cloned using positional cloning methodologies, and this has become a routine procedure over the last few years, greatly aided by the Sanger genome sequencing project.

Upon identifying the genes causative for the mutant phenotypes, the respective mammalian orthologues can be used in interference studies (Luo et al., 2004) in osteoblast cell lines to address the question of whether the function of these genes/ proteins has been conserved. This is an important aspect of these studies, as it will provide a direct angle to pathological conditions in humans. The zebrafish mutant phenotypes, in which a gene is inactivated via chemical mutagenesis, provide surrogate readouts for situations where corresponding mammalian proteins are blocked via small compound molecules, and are therefore highly relevant. Combining the information gained from whole organism studies in fish with mammalian cell culture experiments will be extremely informative in identifying key components of osteoblast function, even though, as mentioned earlier, cell culture studies to investigate mineralization have limitations.

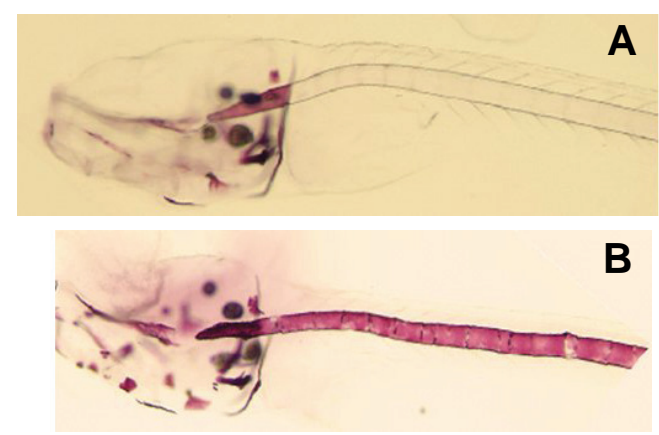

Fig. 3. Alizarin red staining of wild-type (A) and sibling stockstijf mutant embryo (B). Note the completely over-ossified notochord in the mutant embryo.

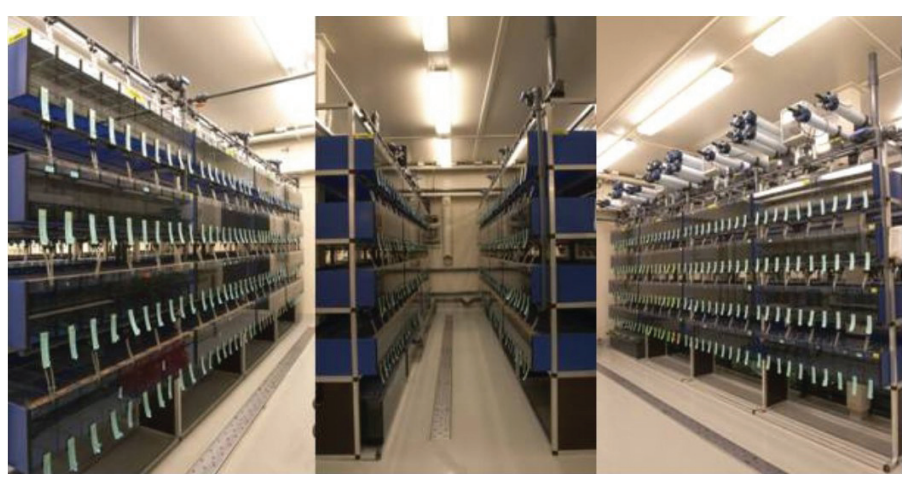

Fig. 4. Serial glass aquarium tanks at the Hubrecht Institute.

Negative regulators of bone formation have not been identified so far in a systematic, genome wide approach. Few of these regulators have been found in mice, and identifying more genes that limit bone formation is clearly an important aspect of understanding osteoblast function. In recent years, the foundation was laid for identifying and molecularly cloning these genes and the outcome of these studies is likely to have a major impact in the field by generating data sets that are of high relevance to cell biologists and medical researchers, including those in the pharmaceutical industry.

\section{A whole-animal GPCR library}

Modern drug development focuses on specific protein classes such as kinases, G protein-coupled receptors (GPCRs), and secreted molecules. Single members of these protein classes are commonly screened for their involvement in a specific indication, but whether blocking a particular protein function has a phenotypic consequence can only be established after a significant amount of effort has already been invested. This is time-consuming and expensive, and it would seem desirable to construct libraries of vertebrate models that are 'ready-to-use' for most or all kinases, for example. In other words, if one had a library of knockout animals covering all kinases or GPCRs, one could immediately ask whether kinase $X Y Z$ is involved in angiogenesis or osteogenesis. Knowing the loss-of-function phenotype for this specific kinase, it would be considerably easier to predict whether this is a protein that warrants screening chemical compound libraries for compounds antagonizing its function.

In the mouse, the method of generating targeted knock-outs is expensive and time-consuming, and it will take a few more years before a mouse library of such dimensions is available to the scientific community. In zebrafish, however, generating mutants using TILLING is a method that has been implemented successfully to provide hundreds of mutants in a comparatively short time frame. In brief, a library of independently mutagenized adult fish, all heterozygous for hundreds of randomly induced mutations, is maintained as a 'shelf library'. DNA from each fish is used to amplify and sequence exons for a given gene of interest (Wienholds et al., 2002). Software-supported heteroduplex analysis then identifies possible mutations, and those inducing alterations to the putative protein can be followed up. The single carrier fish which corresponds to a given mutation can then be outcrossed in order to establish a working stock of fish, and the mutation is bred to homozygosity (Wienholds et al., 2002; Wienholds et al., 2003; Wienholds and Plasterk, 2004). It should be remembered that 
A

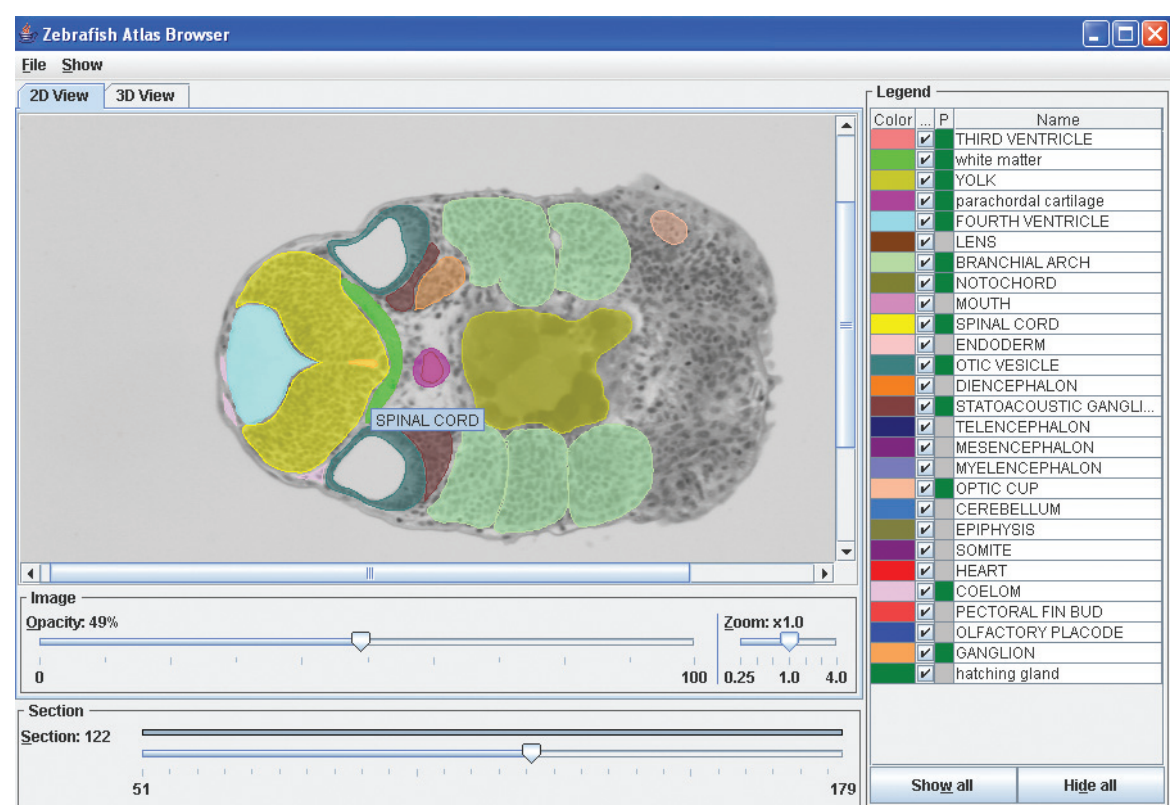

B

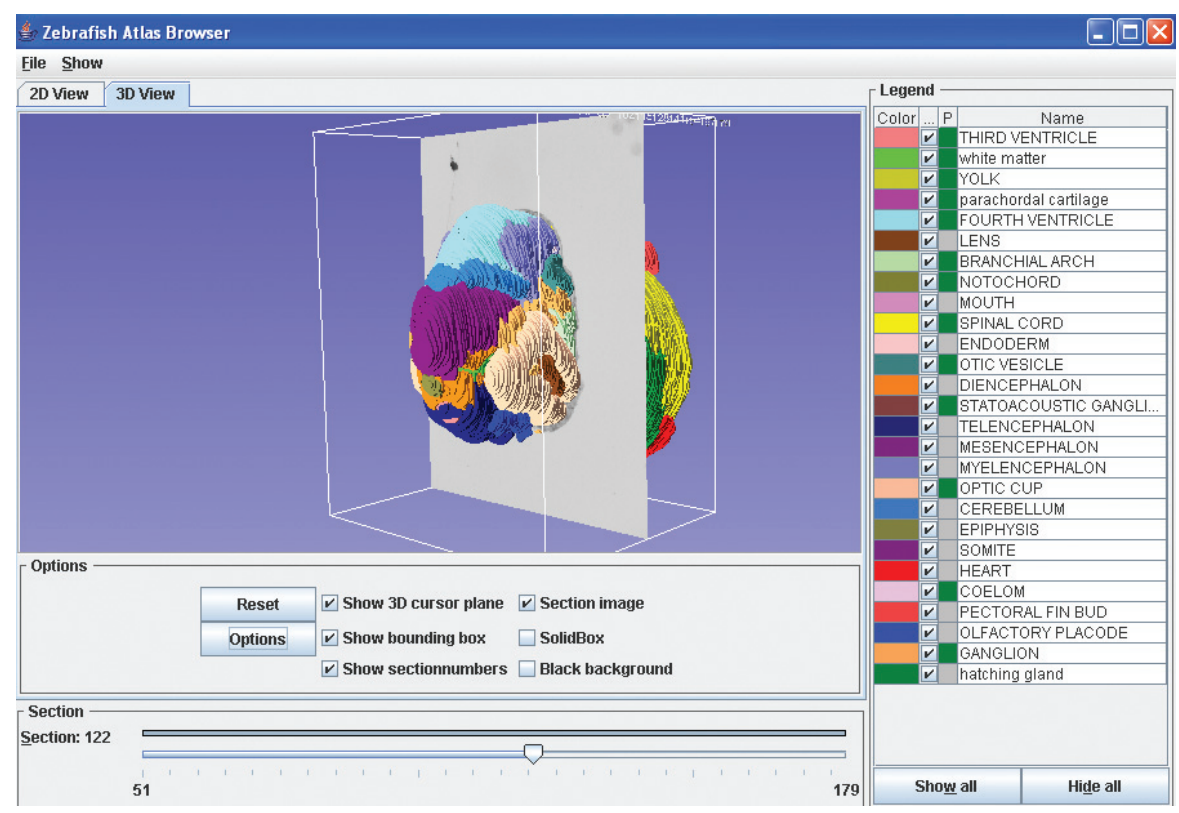

Fig. 5. Screen shots from the Leiden University zebrafish atlas (courtesy Fons Verbeek). (A) $3 d$ embryo showing tracing of structures on an image of a histological section. Note that different structures are assigned different labels and colours. (B) Embryo at 3d., in 3D reconstruction. Now the differently traced structures are visible as distinct $3 D$ objects, and retain their identifications. See http://bio-imaging.liacs.nl/atlasbrowserstart.htm/ for further information.

such large-scale screens are possible in the zebrafish, because their small adult size means that multiple aquaria (Fig. 4) can be economically maintained.

This method of screening for alleles will of course generate not only loss of function alleles, but also hypomorphs, which in many cases will be extremely useful as they provide information about phenotypic effects in partial loss-of-function situations.
Therefore, it might be feasible in zebrafish to accomplish the above-mentioned ambitious aim of generating a whole-animal knock-out library. An attractive gene family for this would be GPCRs (Luttrell, 2008). GPCRs comprise a family of about 1100 proteins within the vertebrate genome. They are popular drug targets for the pharmaceutical industry, and are encoded by single exon genes (which, for technical reasons outlined above, is a considerable advantage when generating the library).

\section{Drug delivery in zebrafish models}

Zebrafish can be exposed to a drug systemically simply by adding it to the aquarium water. If embryos are being used, then the test compound is added to the relatively tiny volume of water in the multiwell plate that houses the embryo. Thus the use of embryos as test models is attractive in cases where the test compound is particularly expensive or scarce. In contrast to systemic administration, drugs can be delivered locally into the tissues by electroporation, or via the surgical implantation of microcarriers loaded with a compound. We suggest that there could be several advantages to administering test compounds on microcarriers, rather than systemically, in zebrafish developmental assays:

(i) economical use of precious test compounds: only a tiny amount of drug is consumed if it administered on a microcarrier

(ii) bioavailability: the drug is delivered directly into a tissue which it might not reach if it were simply added to the aquarium water. This could be true of compounds which are poorly absorbed or rapidly metabolised

(iii) avoidance of systemic toxicity: local targeting of drugs allows a high concentration to be achieved in a limited tissue compartment without producing systemic toxicity

(iv) production of local concentration gradients: the biological properties of some compounds (e.g. morphogens) are only expressed when the compound is present as a local concentration gradient. Such a gradient can be established by diffusion from a microcarrier loaded with drug

There are major disadvantages to administering drugs to embryos on microcarriers. Such procedures are invasive, and may cause bleeding or infection. Further, the intricate microsurgery involved needs to be performed by a skilled technician. It will be a major technical challenge to automate these delicate surgical procedures so that they can become components of high-throughput screens. Although electroporation (Hendricks and Jesuthasan, 2007; Thummel et al., 2006) and robotised microinjection (Wang et al., 2007) are certainly options for the local administration of com- 
pounds in zebrafish, we shall concentrate here on the use of microcarriers.

We are currently exploring the engineering and chemistry of implantable biomaterials for drug delivery (Gerritsen et al., 2000; Kros et al., 2001; Kros et al., 2002), and are also examining the effects on osteogenesis of implantable ceramic matrices (Kruyt et al., 2006; Mendes et al., 2004; Yuan et al., 2006a; Yuan et al., 2006b). Other implanted microcarriers for drug delivery in embryos or regenerating tissues include fragments of Silastic $\circledast$ silicone rubber (Dow Corning) (Del Rincon and Scadding, 2002; Scadding, 1988).

Microbeads are routinely used to deliver retinoic acid (RA) and growth factors to zebrafish embryos (Hyatt et al., 1996; Reifers et al., 2000; Reim and Brand, 2002; von der Hardt et al., 2007). In some experiments, RA was delivered using stryrene-divinyl benzene co-polymer anion exchange resin beads, formate form (Hyatt et al., 1996); agarose Affigel blue beads for Bone morphogenetic protein-2 (von der Hardt et al., 2007); heparin acrylic beads for Fibroblast growth factor 8 (Reifers et al., 2000). Affigel beads have been used for implanting Sonic hedgehog protein in the chick (Scherz et al., 2007).

Although microbeads are used in embryo experiments, major difficulties are faced when attempting to target compounds into the caudal fin blastema of the adult zebrafish. The blastema is extremely friable and easily damaged, and beads often fall out because of the swimming movement of the fish. And so, to the best of our knowledge, there are no successful reports of the blastema being targeted with microbeads. Our approach is to implant the bead at the proximal margin of the blastema, in the inter-ray region, so as not to disrupt the wound epidermis. In a proof-of-concept study, we have successfully used microcarriers to modulate fin regeneration using RA (for methods and data analysis, see Supplementary Material).

We soaked the microcarrier beads in RA because the kinetics of its release from microcarriers are known (Eichele et al., 1984). Furthermore, RA, can influence the pattern of connective tissue differentiation in embryonic chick limb and in the regenerating axolotl limb (Brickell and Tickle, 1989; Del Rincon and Scadding, 2002), as well as in the developing zebrafish pectoral fin bud (Gibert et al., 2006). In the regenerating urodele limb, it can proximalise positional values of blastema cells (Maden, 1982); reviewed by (Stocum, 1996) and modulate the expression of Hox genes (Simon and Tabin, 1993).

Systemic application of RA to the regenerating zebrafish fin (by addition to the tank water) results in suppression and abnormalities of regeneration (Ferretti and Géraudie, 1995; Géraudie et al., 1993; Géraudie etal., 1994; White etal., 1994). The severity of the effects depends on the concentration used, length of the treatment, and the time at which the treatment is performed following amputation. However, in none of the conditions tested did RA affect growth of the skeletal components of the fin and the length of a regenerated fin is comparable to that of controls (Ferretti and Géraudie, 1995; Géraudie et al., 1994).

In our study (see Supplementary data), the predominant phenotypes induced by RA were notching of the regenerating fin margin, due to suppression of outgrowth in the inter-ray region. This effect correlated with dose of RA and duration of exposure, indicating that RA had been effectively targeted to the blastema Otherwise, there was no morphological evidence of altered pat- tern formation of the fin skeleton at any dose. This is in contrast to the dramatic effects of RA beads on patterning of the chick limb skeleton under certain conditions (Tickle et al., 1982). We were also unable to find any evidence of a proximalising effect of retinoic acid on the skeleton.

\section{Computer imaging tools for zebrafish models}

At present, biological research information is preferred in a digital computer readable form so that this information can be shared and linked to other digital resources. This is particularly important for model system information resources. We have worked out a digital atlas for zebrafish embryo development and made it available through internet. This atlas is based on threedimensional models (Fig. 5). For the support of zebrafish research in biomedicine and molecular genetics it is important to have a framework available with which findings can be integrated with standard morphology. The atlas of zebrafish development is such a framework; it comprises a number of canonical stages of zebrafish embryo development, i.e. $24,36,48$ and 72 hours post fertilisation.

Zebrafish development can be visualized in various ways. For the atlas, we use bright field microscopy of histological sections in order to visualise micro-anatomy and to visualize cells in situ. Visualizing micro-anatomy and development requires the information to be three dimensional. Consequently, our approach is based on reconstructing serial sections to $3 \mathrm{D}$ volumes and $3 \mathrm{D}$ models (Fig. 5).

In our approach, each section is processed to a section image which is acquired with a CCD camera mounted on the microscope. A high-resolution image, composed of adjacent images, is acquired providing resolution at the cellular level (Verbeek and Boon, 2002). The anatomical structures in each section image are annotated with specialized software that produces 3D models (Verbeek et al., 2000; Verbeek et al., 2002).

For each stage, a 3D model is made available, consisting of the anatomical structures that can be distinguished at that particular stage. Standard staging conventions and anatomical nomenclatures are used. In order to be able to use these conventions in accessing other information systems, we have compiled it, enriched it and extended its granularity as an ontology (Belmamoune and Verbeek, 2007). The standard nomenclature is commonly referred to as the zebrafish ontology.

The atlas can be browsed with a number of applications that are made available through the internet (URL: bio-imaging.liacs.nl; Verbeek et al., 2000). The zebrafish ontology is the pivot in addressing the atlas of development. The ontology provides the glue to further link the browsers to other zebrafish resources, e.g. ZFIN or Ensmbl (Belmamoune and Verbeek, 2006).

The atlas can be used to analyse patterns of gene expression. In addition to the atlas models, we have elaborated on an information system for spatiotemporal patterns of gene expression. This system includes patterns of gene expression for a number of marker genes, and is transparently integrated with the atlas (Belmamoune and Verbeek, 2006). The patterns of gene expression are realized through whole mount in situhybridization using CLSM with the zebraFISH protocol (Welten et al., 2006).

Having these information systems on hand allows comparing experimental results in a direct and comprehensive manner. As 
such these frameworks are tools to have aboard in a high throughput setting; morphological observations can be linked directly to patterns of gene expression and these patterns can be further probed in 3D together with other information available (Belmamoune and Verbeek, 2006; Richardson and Verbeek, 2003). In addition, machine learning approaches are invoked to compare findings to results in other model species. In this manner we learn about the delicate interplay of genes and networks in broader context. Such integrative approaches, including interoperable model system databases equipped with proper software agents, will, in the near future, facilitate further breakthroughs.

\section{Infection, inflammation and the immune system}

In the last decade, zebrafish embryos have been increasingly used as a model to study the immune system. More recently, they have also been used as hosts for infectious disease studies. As a result of these studies, it has been found that zebrafish have both an adaptive ( $\mathrm{B}$ - and $\mathrm{T}$-cell-mediated) immune response, and a well-developed innate immune system. The zebrafish immune system shows many points of conservation with that of mammals (Kasahara et al., 2004; Schorpp et al., 2006; Trede et al., 2004). Here we describe some of our own results, in the context of other studies.

\section{Infectious disease}

Because adaptive immunity develops at a slower pace than innate immunity, the zebrafish model allows for dissection of the contribution of both systems to infection. To date, different experimental infection models, mainly concerning bacterial pathogens, have been described to study various aspects of pathogenesis. One of the major advantages of the zebrafish is that the model is amenable to high-throughput screening. Forward genetic screens can be performed in the zebrafish model to identify host immune factors and also bacterial mutants. This possibility has not been exploited yet for host factors, mainly because large-scale aquarium facilities are needed. However, the strategy is expected to deliver its first results soon, because many infection models have now been established.

Adult zebrafish have been used as hosts for Listeria monocytogenes(Menudier etal., 1996), Streptococcussp. (Neely et al., 2002), Mycobacterium marinum (Prouty et al., 2003) and Edwardsiella tarda (Pressley et al., 2005). Concerning pathogens, Miller and Neely (2005) described a study where more than 1000 mutants of Streptococcus iniae were tested in a signaturetagged mutagenesis approach for reduced virulence. $S$. iniae is able to cause invasive infections, mainly in fish species, but occasionally also in humans. The large-scale screen for bacterial virulence factors resulted in the identification of some known or expected virulence candidates, such as capsule biosynthesis genes, transcription regulators and the DegP encoding gene, as well as a number of unidentified but conserved genes (Miller and Neely, 2005). These results show that large screens can be performed to identify novel virulence factors.

Besides the possibility of large screens, zebrafish embryo models have the advantage that bacterial infections can be analysed in real-time. Zebrafish embryos are translucent, and most components of the innate immune system are already active at 30 hours post-fertilisation (Lieschke et al., 2001). Real-time analysis of infection have been reported for the fish pathogen $M$. marinumand the mammalian pathogen Salmonella typhimurium after microinjection of GFP or DsRed-expressing bacteria (Davis et al., 2002; van der Sar et al., 2003). For Salmonella these experiments showed that, although the bacteria mainly reside within macrophages, they most actively divide extracellularly as microcolonies. The known attenuated LPS O-antigen Ra mutant of $S$. typhimurium was also attenuated in zebrafish embryos (van der Sar et al., 2003).

To date, most zebrafish infection experiments have been performed using the fish pathogen M. marinum. This model is broadly accepted as a useful alternative for tuberculosis research. M. marinum has a number of advantages: it grows more rapidly compared to $M$. tuberculosis, it is less pathogenic for the scientist and, importantly, this mycobacterium is a natural pathogen of zebrafish in which it gives rise to the chronic infection known as fish tuberculosis (Kaattari et al., 2006). In addition, $M$. marinumis genetically closely related to M. tuberculosis, allowing cross-complementation experiments and translation of research findings.

In adult zebrafish, $M$. marinum infections give rise to highly distinctive granulomas (Fig. 6), some of which are caseating (van der Sar et al., 2004). Interestingly, M. marinum infection of zebrafish embryos also resulted in the clustering of embryonic macrophages that resembled the beginning of granuloma formation (Davis et al., 2002). This would mean that granuloma formation is independent of an adaptive immune response, which is not developed yet in these young embryos.

To analyse this in more detail, the expression of mycobacterial genes that were known to be upregulated in macrophages or in mature granulomas was determined in these embryos. These experiments convincingly showed that the microenvironment of the cluster of infected macrophages induced expression not only of macrophage activated genes, but also of granuloma activated genes of mycobacteria (Davis et al., 2002). In other experiments it was shown that granulomas are in fact highly dynamic struc-
Fig. 6. Granuloma formation in M. marinuminfected 6-day-old zebrafish larvae after ethambutol or control treatment. Presence or $a b$ sence of bacteria is visualized by fluorescence (bacteria are visible as black spots in (A). Treatment of 4-day-old embryos $(n=20)$ for 2 days with ethambutol resulted in clearance of the infection (B) whereas control treated embryos (A) still contain bacteria. (photo source: A. van der Sar, unpublished data).

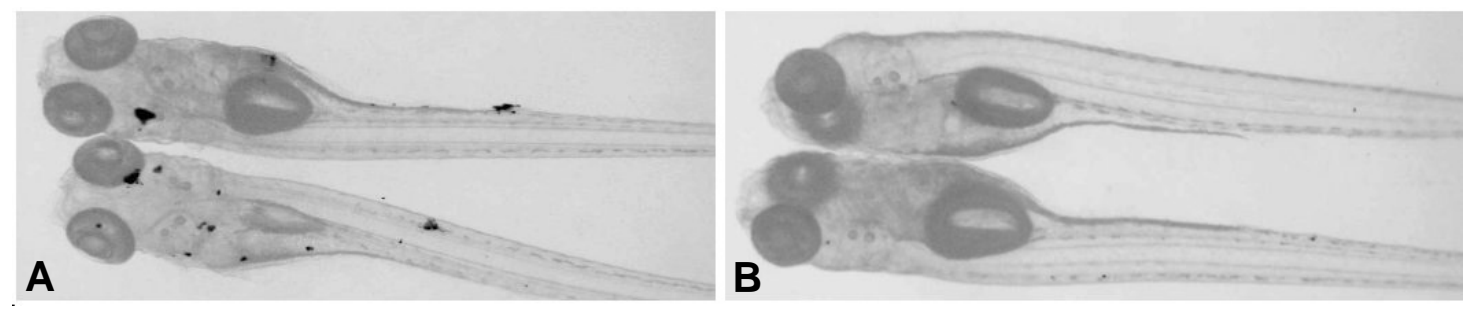




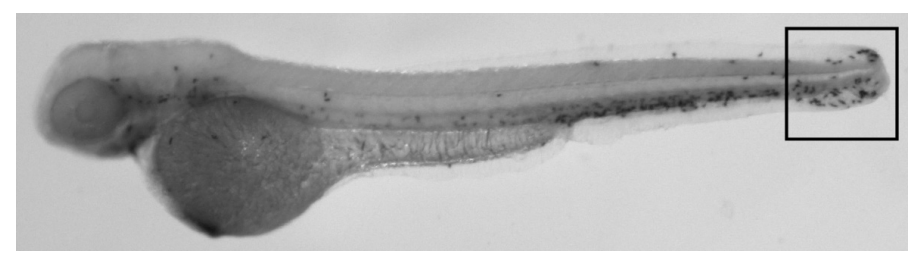

Fig. 7. Neutrophils (dark spots in boxed area) of a 2-day-old zebrafish embryos are massively attracted to a wounding site inflicted by damaging the caudal fin tip with a sharp needle. Left lateral aspect, caudal is to the right. Neutrophils are visualized here by histochemical staining for myeloperoxidase (MPX) activity (Lieschke et al., 2001). Additionally, transgenic lines with fluorescently marked neutrophils enable live imaging of the inflammatory response (Mathias et al., 2006; Meijer et al., 2008; Renshaw et al., 2006).

tures, and that superinfection results in newly infected macrophages that are homing to already established granulomas (Cosma et al., 2004).

To further establish the zebrafish tuberculosis model, it was shown that $M$. marinum mutants of important $M$. tuberculosis virulence factors, such as the cell surface protein Erp and the secreted ESAT- 6 and CFP-10 proteins, are attenuated in the zebrafish model (Cosma et al., 2006; Gao et al., 2006; Volkman et al., 2004). The latter genes are located in the well-known RD1 region, which is the distinctive mutation in the tuberculosis vaccine strain BCG. Injection of this mutant in zebrafish embryos resulted in aberrant granuloma formation in zebrafish embryos (Cosma et al., 2006; Gao et al., 2006; Volkman et al., 2004). This finding inspired us to do a forward genetic screen to identify $M$. marinum mutants impaired in granuloma formation in zebrafish embryos. The first results of this screen are that $2 \%$ of the transposon knock-out mutants show an aberrant phenotype and that we do find additional RD1 mutations, as was to be expected. The new granuloma-impaired mutants will be tested for their vaccination potential.

The granuloma-like clustering of macrophages upon $M$. marinum infection, in combination with the possibility of real time imaging makes this zebrafish embryo infection model also suitable for compound screens in search for anti-tuberculosis drugs. Using fluorescent mycobacteria not only the bactericidal effect of the compounds added to the infected embryos can be measured in vivo by the presence or absence of fluorescence, but also the effect of the compounds on granuloma formation can be visualized. Treatment of infected 4-day-old zebrafish embryos with ethambutol, a known and commonly used antimycobacterial agent, resulted in the clearance of the $M$. marinuminfection (Fig. 6 ) indicating the feasibility and the power of such an in vivo compound screen (van der Sar unpublished results). The advantage of this screen is that it permits the identification of drugs that may not be active in vitro, but are active against pathogenic mycobacteria in vivo.

The zebrafish embryo infection model is also used to study the expression and involvement of host factors. For instance, morpholino-based gene-knockdown experiments were used to show that the adaptor protein Myeloid Differentiation factor 88 (MyD88) plays an important role in the innate immune response against $\mathcal{S}$. typhimurium infection (van der Sar et al., 2006) and that the peptidoglycan recognition protein 5 (PGLYRP-5) is essential for host defence against both $\mathcal{S}$. enterica and $B$. subtilis (Li et al., 2007). In a somewhat different approach, morpholinos were used to delay the formation of macrophages by targeting the myeloid transcription factor gene pu.1. Subsequent infection with $M$. marinumshowed that macrophages have, in fact, a double role in infection: they limit the multiplication of the pathogen and also promote tissue dissemination (Clay et al., 2007).

Microarray studies of infected fish create the opportunity to analyse and compare host responses to different pathogens. As such, they could help identify specific transcriptional profiles that could characterise infectious disease states. For instance, we studied the effect of infection by $M$. marinum on zebrafish host gene expression using microarrays. Immune-specific mRNAs, such as the Toll-like receptors, as well as metalloproteinases such as mmp9, were found to be up-regulated (Meijer et al., 2005).

From the above mentioned models it is clear that infection studies in zebrafish models not only help us to understand which factors of the immune system are important in a particular infection but also make a difference in our understanding of the hostpathogen interaction.

\section{The innate immune system and its role in inflammation}

The innate branch of the zebrafish immune system develops as early as the first day of embryogenesis (Herbomel et al., 1999) and within two days, distinct macrophage and granulocyte populations can be identified by both morphological characteristics and marker gene expression (Crowhurst et al., 2002). Due to the transparency of the zebrafish embryo, the development and behaviour of its innate immune cells can be clearly and noninvasively imaged in the living organism (Herbomel and Levraud, 2005). The process of haematopoiesis in zebrafish shares strong conservation with that in mammals.

In all vertebrates, including the zebrafish, two waves of haematopoiesis occur (Davidson and Zon, 2004). The first wave, known as primitive haematopoiesis, occurs in the extra-embryonic yolk sac of mammals and in two intraembryonic locations in zebrafish: the intermediate cell mass and the rostral blood island, arising from posterior and anterior mesoderm, respectively. The second wave, known as definitive haematopoiesis, begins in both mammals and zebrafish in a region known as the aorta-gonadmesonephros (AGM) that is associated with the ventral wall of the dorsal aorta. Later during development the niches of definitive haematopoiesis shift to other intermediate and final locations, such as the fetal liver, placenta, thymus and bone marrow in mammals, and the caudal haematopoietic tissue, thymus and kidney in zebrafish (Murayama et al., 2006). In the zebrafish embryo, primitive haematopoiesis occurs during the first day of development and definitive haematopoiesis begins during the second day.

Since the adaptive immune system is not mature until several weeks after fertilization (Davidson and Zon, 2004), the zebrafish embryo is particularly suitable for functional analysis of the innate immune system. Importantly, as mentioned above, zebrafish embryos express a broad range of Toll-like receptors (TLRs), one of the major classes of innate immune receptors in other vertebrates (Meijer et al., 2004). Moreover, interference with the function of an essential TLR adaptor molecule, MyD88, impairs the ability of zebrafish embryos to clear a bacterial infection (van 
der Sar et al., 2006). Zebrafish embryos also express conserved cytokines and chemokines, such as TNF $\alpha$, IL- $1 \beta$ and IL-8, in response to bacterial infections (Pressley et al., 2005; Stockhammer et al., 2009). Furthermore, zebrafish embryos express a virus-induced interferon system ancestral to that of other vertebrates (Levraud et al., 2007). Finally, embryonic neutrophils have been shown to participate in acute inflammation caused by sterile tissue injury (Lieschke et al., 2001). Taken together, the early innate immune response of embryonic zebrafish appears well conserved with responses in adult mammalian animal models.

Inflammation of injured or infected tissues is essential during normal immune responses. However, failure to limit the inflammatory response, or to resolve it in a timely manner, is the cause of many chronic inflammatory diseases. The ease with which an inflammatory response can be induced and visualized in zebrafish embryos (Fig. 7) makes this an attractive model that could be developed into a rapid screening system. Such a system could be used to screen candidate drugs for effects on the dampening of neutrophil recruitment, or on the acceleration of the resolution phase of inflammation. Several transgenic zebrafish lines with fluorescently marked immune cell types have recently become available, and have been used to image the participation of early myeloid precursors and differentiated neutrophils in acute inflammation (Hall etal., 2007; Mathias et al., 2006; Meijer et al., 2008; Redd et al., 2006; Renshaw et al., 2006). The neutrophilic inflammation of injured zebrafish embryo tissue is normally resolved within 12-24 hours, and the resolution was shown to involve both neutrophil apoptosis and the retrograde chemotaxis of neutrophils from the inflammatory site back to the vasculature (Mathias et al., 2006; Renshaw et al., 2006).

Evidence that the inflammatory response in zebrafish embryos is sensitive to pharmacological manipulation has recently been reported in the literature. Treatment of embryos with nocodazole, a microtubuledepolymerising drug, impaired the re-
A

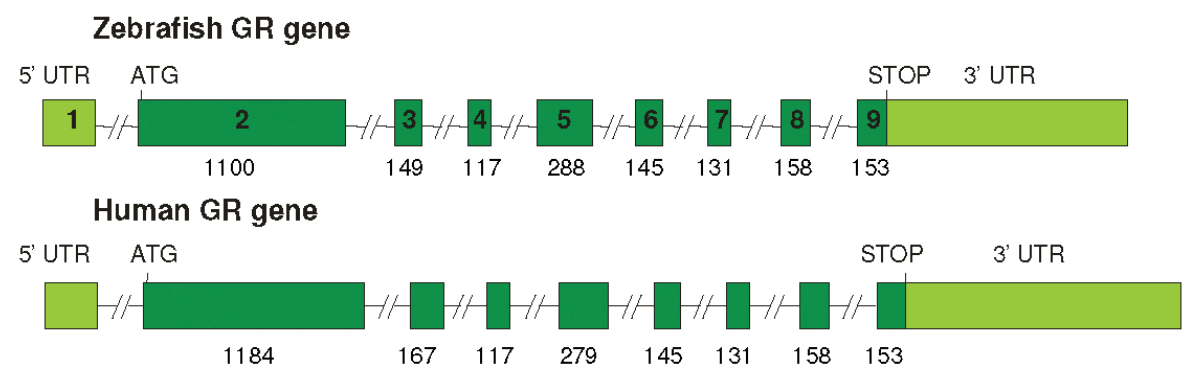

B

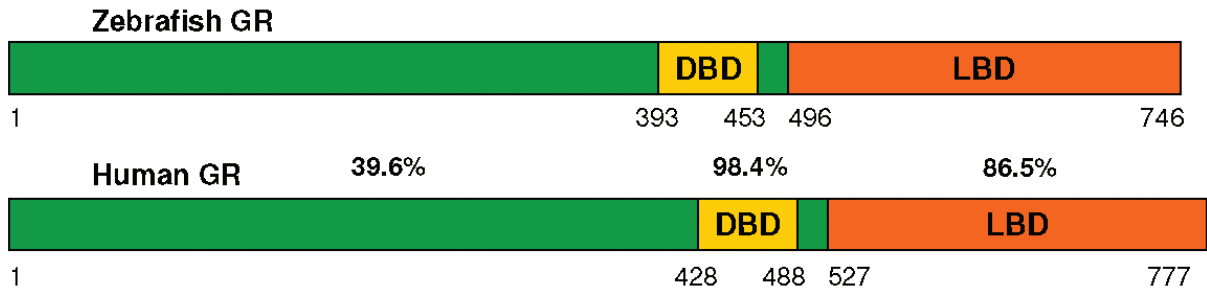

C

ZGR (1) ------MDQGGLENGK--KRDERLNTLDYNKRATEGILPRRIQSTMSVAPTSMVPQAGPMMQPVSG hGR (1) MDSKESLTPGREENP SSVLAQERGDVMDFYKTLRGGATVKVSAS SP SLAVASQSDSKQRRLLVDFP

ZGR (59) DIPNGLSNSPTLEEHTSSVSSIFGDDSELKLLGKEQRALQQQTLVPFTLGDSLSGLEAS IADLNNP hGR (67) KGSVSNAQQPDLSKAVS LSMGLYMGETETKVMGNDLGFPQQGQISLSSGETDLKLLEES IANLNRS

ZGR (125) SPSMDSLIGGVDPNLFP LKTEDFSPMIKGDMDLD-QDSFGHIGKDVDVGNHKLFSDNTLDLLQDFE hGR (133) TSVPENPKSSASTAVSAAPTEKEFPKTHSDVSSEQQHLKGQTGTNGGNVKLYTTDQSTFDILQDLE

ZGR (190) LDG-SP---------SDFYVADDAFLSTIG--EDALISELPTNLDRDSKAAVSGSNTLNGTASSS hGR (199) FSSGSPGKETNESPWRSDLLIDENCLLSP LAGEDDSFLLEGNSNEDCKP LILPDTKPKIKDNGDLV

zGR (243) LSTANTS ILPNIKVEKDS I IQLCTPGVIKQENTGASYCQG--------GLHSTP INICGVTTSSGQ hGR (265) LSSPSNVTLPQVKTEKEDFIELCTPGVIKQEKLGTVYCQASFP GANI I GNKMSAISVHGVSTSGGQ

zGR (301) SFLFGNSSPTAVVGLQKDQKPDFNMYTPLTSSGDGWSRSQG-----FGNVSGMQQRASLCF SKNF, hGR (331) --MYHYDMNTASLSQQQDQKP IFNVIPP IPVGSENWNRCQGSGDDNLTSLGTLNFP GRTVF SNGYS

zGR (362) SSPYSRPEDSTATSSAGGKTG--THKICLVCSDEASGCHYGVLTCGSCKVFFKRAVEGQHNYLCAG hGR (395) S-PSMRP DVSSPP SSSSTATTGPPP KLCLVCSDEASGCHYGVLTCGSCKVFFKRAVEGQHNYLCAG

zGR (426) RNDCIIDKIRRKNCPACRFRKCLMAGMNLEARKSKSKARQAGKVIQQQS IPERNLPP LPEARALVP hGR (460) RNDCIIDKIRRKNCPACRYRKCLQAGMNLEARKTKKKIKGIQQATTGVSQETS---ENPGNKTIVP

zGR (492) KPMPQLVPTMLSLLKAIEPDTLYAGYDSTIPDTSVRLMTTLNRLGGRQVISAVKWAKALPGFRNLH hGR (523) ATLPQLTPTLVSLLEVIEPEVLYAGYDSSVP D STR IMTTLNMLGGRQVIAAVKWAKA IP GFRNLH ZGR (558) LDDQMTLLQCSWLF IMSFGLGWRSYQHCNGNMLCFAPDLVINEERMKLPYMSDQCEQMLKISNEFV hGR (589) LDDQMTLLQYSWMFLMAFALGWRSYRQS SANLLCFAPDI I INEQRMTLPCMYDQCKHMLYVSSELH zGR (624) RLQVSTEEYLCMKVLLLLNTVPKDGLKSQSVFDELRMSYIKELGKAIVKREENSSQNWQRFYQLTK hGR (655) RLQVSYEEYLCMKTLLLLSSVPKDGLKSQELFDEIRMTYIKELGKAIVKREGNSSQNWQRFYQLTK zGR (690) LLDSMHDLVGGLLNFCFYTFVNKSLSVEFPEMLAEI ISNQLPKFKDGSVKPLLFHQK hGR (721) LLDSMHEVVENLLNYCFQTFLDKTMS IEFPEMLAEI ITNQIPKYSNGNIKKLLFHQK

Fig. 8. Homology between the zebrafish and human glucocorticoid receptor. (A) The zebrafish and human glucocorticoid receptor gene. The organization of the gene is well conserved. Both genes comprise nine exons of which the first is non-coding and the ninth contains the sequence encoding the 3'UTR. Note the similarity in length of the exons. (B) The zebrafish and human glucocorticoid receptor. Indicated are amino acid numbers and percentages of similarity for the $\mathrm{N}$ terminal domain, the DNA binding domain (DBD) and the ligand binding domain (LBD). (C) Alignment of zebrafish and human glucocorticoid receptor. Identical amino acids are indicated in yellow, similar amino acids in green. 
cruitment of immune cells to wounds, and this effect could be suppressed by treatment with the Rho-kinase inhibitor Y-27632 (Redd et al., 2006). Furthermore, treatment of embryos with the caspase-inhibitor zVD.fmk inhibited the resolution of woundinduced neutrophilic inflammation (Renshaw et al., 2006). Treatment with a non-steroidal cyclooxygenase 2 (COX-2) inhibitor, frequently used as an anti-inflammatory, also impaired zebrafish neutrophil motility (Mathias et al., 2007).

These studies suggest that zebrafish-based wounding assays could be developed into anti-inflammatory drug screens. To adapt wounding assays into high-throughput drug screens, several steps in the procedure require automation, including the sorting and arraying of embryos, the wounding itself, and the image analysis process. In addition to drug screening, it is also attractive to utilize zebrafish mutagenesis screens to identify novel mediators of the inflammatory response. The first zebrafish chronic inflammation mutant was recently described, and was shown to have an insertion in the hepatocyte growth factor activator inhibitor 1 (hai1) gene, which regulates inflammatory responses through the serine protease Matriptase 1 (Mathias et al., 2007). Genetic or chemical screens using this inflammation mutant could be powerful means to uncover molecules that modify the Hai1Matriptase1 pathway or inflammation in general. We will now consider the related topic of zebrafish screens for glucocorticoid drugs.

\section{Glucocorticoid drug screens}

As described above, the zebrafish can be developed into a powerful tool for the screening of anti-inflammatory drugs. It can therefore be used as a model system for the development of novel glucocorticoids, since this class of steroid drugs have strong antiinflammatory activity and are therefore commonly used to treat immune-related diseases such as rheumatoid arthritis and asthma. Using neutrophil migration after tail wounding as a readout, it has indeed been demonstrated that the synthetic glucocorticoid beclomethasone displays anti-inflammatory activity in 2-day-old zebrafish larvae (Mathew et al., 2007).

In addition to their anti-inflammatory actions, the side effects of glucocorticoid drugs can also be studied in the zebrafish model system. Recently, a zebrafish model for glucocorticoid-induced osteoporosis, the most severe side effect of chronic systemic glucocorticoid treatment in humans, has been developed. This assay system is based on the visualization of skeletal structures of zebrafish larvae. They are treated with calcium-binding dyes such as calcein and alizarin red, taking advantage of the transparency of these organisms (Du et al., 2001; Fleming et al., 2005). As a proof of principle, treatment of 5-day-old zebrafish larvae with prednisolone, a glucocorticoid that is widely used clinically, significantly reduces bone formation in this assay (Barrett et al., 2006).

An advantage of the zebrafish as a model system for the screening of glucocorticoid drugs is the relatively high level of similarity between the human and zebrafish glucocorticoid system, as we have recently shown (Schaaf et al., 2008). First, the main endogenous glucocorticoid hormone in zebrafish is cortisol, as it is in humans. In the most commonly used rodent model systems, by contrast, this is corticosterone. Second, the zebrafish contains only a single gene encoding the glucocorticoid receptor (GR), which mediates the effects of glucocorticoids. Most fish contain two copies of this gene as a result of a genome duplication during evolution. This led to the presence of two GR isoforms: GR1 and GR2 (Stolte et al., 2006).

It appears that the zebrafish contains only the gene encoding GR2, making it unique among well-studied fish species (Schaaf et al., 2008). The receptor that is encoded by this zebrafish GR gene shows a high level of similarity with the human GR (Fig. 8), especially in the DNA-binding domain (98\%) and the ligandbinding domain (87\% (Schaaf et al., 2008). A third point of similarity is that the zebrafish contains a GR splice variant with high similarity to the human GR $\beta$ (Schaaf et al., 2008). As a result of alternative splicing in humans, GR $\alpha$ and GR $\beta$ occur. GR $\alpha$ is the classical GR that acts as a ligand-activated transcription factor. GR $\beta$ does not bind ligand, is transcriptionally inactive and acts as a dominant-negative inhibitor of GR $\alpha$.

Until recently, GR $\beta$ had been found only in humans, so no animal model for this splice variant was available. This was unfortunate, since several studies have indicated a clinical relevance for GR $\beta$. An increased expression level of GR $\beta$ was observed in patients suffering from several immune-related diseases and appears to correlate with resistance to glucocorticoid treatment. The recent discovery of a zebrafish GR $\beta$ provides a unique animal model that can be utilized for the unravelling of the role of GR $\beta$ in the pathogenesis of inflammatory diseases and glucocorticoid resistance. The glucocorticoid system is important not only in inflammation, but also in the stress response, as we shall now consider. Models of stress are based on complex behavioural traits, and represent perhaps the greatest challenge for anyone trying to overcome scepticism about the transferability of models from mammals to zebrafish.

\section{The zebrafish as a new model of early-life stress: relevance for the study of psychopathologies}

The central question in the field of psychopathology is: why do some people become ill while others remain healthy? One factor is an individual's genetic makeup. It is also now increasingly recognized that an individual's exposure to adverse experiences early in their life can play a determinant role in susceptibility to develop major psychopathologies such as depression, anxietylike, autism-like and schizophrenia-like spectrum of disorders (Rutter et al., 2006). The effect of early-life stress on health is believed to be mediated, at least in part, by alterations of the stress-regulating system known as the hypothalamic-pituitaryadrenal (HPA) axis (Levine, 2005).

In the context of this special issue on pattern formation, it is important to recognise that HPA and early-life stress may have effectors in the developmental patterning of the nervous system (Gunnar and Quevedo, 2008). For instance, overexposure to glucocorticoid during rapid periods of brain development may influence the development and patterning of specific brain areas (Clark, 1998; Seckl, 2004). Since glucocorticoids are potent transcription factors, it is primordial to identify their genetic targets (e.g. glucocorticoid-primary responsive genes) to gain an understanding of the molecular underpinnings associated with miswiring of brain areas during critical periods of development 
A
A

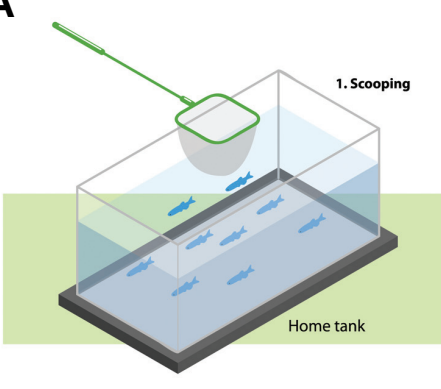

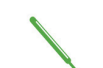

$>$

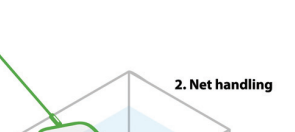

2. Net handling

.

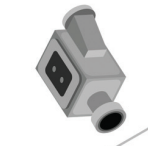

B
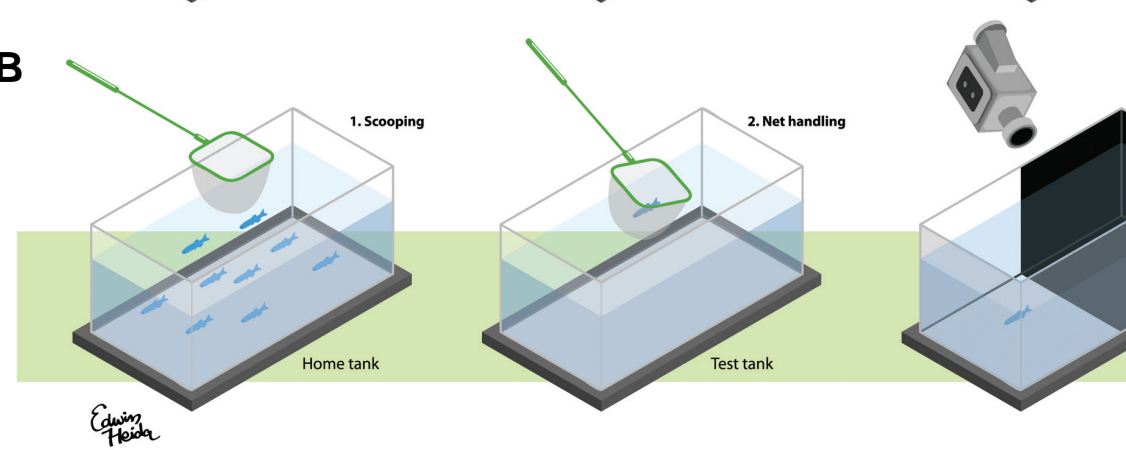

Fig. 9. Schematic illustration of our adaptation of the rodent version of both open field and light/dark box paradigms for use in zebrafish (Champagne, de Kloet and Richardson, unpublished). Zebrafish are individually scooped out of their home tank and placed in a second tank where they undergo net handling stress for $15 \mathrm{~min}$, after which they are observed for their behavioral performance in the Open field test (10 min) (A) and Light/Dark test (5 min) (B) in a third tank. All behavioral sessions are filmed and analyzed with commercial software (Viewpoint S.A., Champagne au Mont d'Or, France).

(Geschwind and Levitt, 2007; Gunnar and Quevedo, 2008; Pagani et al., 2007; Pardo and Eberhart, 2007; Yuii et al., 2007).

Several mammalian (mainly rodent) models have been successful in mimicking HPA axis alterations (i.e. hyper-responsiveness to stress); however, these models are limited in their ability to provide an understanding of the developmental mechanisms leading to such effects (Pryce etal., 2005). This is largely due to the fact the mammalian models are not amenable to non-invasive developmental studies. Because mammalian offspring are relatively inaccessible within the uterus in the prenatal phase, and depend on parental care for survival in the postnatal phase, experimental interventions will themselves invariably introduce a stress effect.

The zebrafish is an attractive alternative to rodent models of early-life stress (Lieschke and Currie, 2007). Zebrafish are particularly suitable in this context because their development is accessible to non-invasive study. Furthermore, there is a great degree of similarity between zebrafish and terrestrial vertebrates (including rodents and humans) with respect to the general organization and functioning of several behavioral and physiological systems, including the stress-regulating system (Gerlai et al., 2000; Gerlai, 2003; Grunwald and Eisen, 2002; Lieschke and Currie, 2007). The equivalent of the HPA axis has been found in zebrafish, where it is referred to as the hypothalamic-pituitary-interrenal axis (Wendelaar Bonga, 1997).

Although counterintuitive, the idea of using zebrafish models to study psychopathologies and brain disorders in general (Guo, 2004; Lieschke and Currie, 2007) is becoming increasing popular and several recent publications are attesting the validity of zebrafish model systems in the fields of autism (Tropepe and Sive, 2003), degenerative disorders (Newman et al., 2007), sleep/insomnia
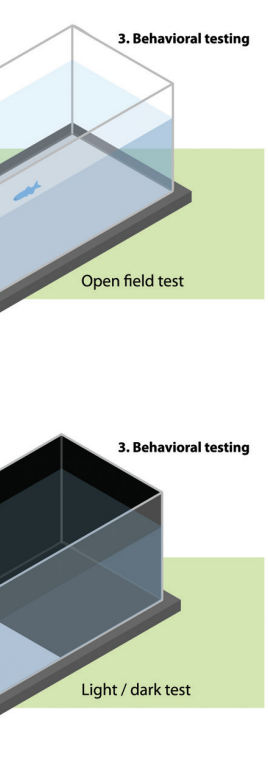

(Yokogawa etal., 2007) and alcohol research (Gerlai et al., 2000).

We are developing a zebrafish model of early-life stress aiming to model alterations of the HPA axis, which are often associated with major psychopathologies such as depression (Gillespie and Nemeroff, 2005; Pariante, 2006). We have also devised methods and protocols to assess endocrine profile as well as stress/ anxiety-like phenotypes in response to an acute stressor customized for zebrafish, such as net handling. We and others have adapted the rodent version of both open field (Prut and Belzung, 2003) and light/dark box (Bourin and Hascoet, 2003) paradigms for use in zebrafish (Fig. 9; see also (Ninkovic and Bally-Cuif, 2006). Our preliminary findings (data not shown) are that zebrafish exposed to handling stress for 15 min displayed hyperactivity. This pattern of behaviour habituated over time and was reminiscent of that of rodents under similar experimental contexts, suggesting adequate test validity (Anisman and Matheson, 2005; Bourin and Hascoet, 2003; Prut and Belzung, 2003). Analysis of these behaviours, and of the developing nervous system at different time points after early-life stress exposure will determine the efficacy of early-life stress paradigms in producing enduring changes in stress-regulating systems.

Ultimately, zebrafish model of early-life stress can be used to identify the nature of glucocorticoid primary-responsive (developmental) genes, as well as their molecular signature (i.e. gene expression profile patterns) under normal vs. pathological (i.e. under stress) brain development using DNA micro-array methodology or other genetic tools (e.g. anti-sense morpholino, knock out, and transgenic zebrafish). Glucocorticoid-responsive genes could be thereafter investigated as potential drug targets. One of the classes of compounds being tested by us on the early life stress system are snake venom toxins. Snakes evolved venom primarily to immobilize their prey (Li et al., 2005) and venoms may contain neurotoxins. One example from the recent literature is Hannalgesin, a long-chain neurotoxin isolated from the venom of the King cobra (Ophiophagus hannah). This compound is 2700 times more powerful than morphine as an analgesic (Pu et al., 1995). It will be interesting to screen other venom toxins for neuropharmacological effects in the zebrafish system. In this context, it can be seen that zebrafish models are suitable for the high-throughput screening required in bioprospecting (the discovery of useful compounds from natural sources).

\section{Acknowledgements}

The authors gratefully acknowledge the support of the Smart Mix Programme of the Netherlands Ministry of Economic Affairs and the Netherlands Ministry of Education, Culture and Science. Additionally, 
A.H.M. and H.S are supported by the EU $6^{\text {th }}$ framework programme grants ZF-MODELS (contract LSHG-CT-2003- 503496) and ZF-TOOLS (contract LSHG-CT-2006-037220). We would like to thank Ben Nelemans for help with image editing and Edwin Heida for drawing Figures 1 and 9.

\section{References}

ABBINK, W. and FLIK, G.(2007). Parathyroid hormone-related protein in teleost fish. Gen. Comp. Endocrinol. 152: 243-251.

AKARSU, A.N., STOILOV, I., YILMAZ, E., SAYLI, B.S. and SARFARAZI, M.(1996). Genomic structure of HOXD13 gene: a nine polyalanine duplication causes synpolydactyly in two unrelated families. Hum. Mol. Genet. 5: 945-952.

AKIMENKO, M.A., MARI-BEFFA, M., BECERRA, J. and GÉRAUDIE, J.(2003). Old questions, new tools, and some answers to the mystery of fin regeneration. Dev. Dyn. 226: 190-201.

AKIMENKO, M., JOHNSON, S., WESTERFIELD, M. and EKKER, M.(1995). Differential induction of four msx homeobox genes during fin development and regeneration in zebrafish. Development 121: 347-357.

AMSTERDAM, A. and HOPKINS, N.(2006). Mutagenesis strategies in zebrafish for identifying genes involved in development and disease. Trends Genet. 22: 473478.

ANISMAN, H. and MATHESON, K.(2005). Stress, depression, and anhedonia: caveats concerning animal models. Neurosci. Biobehav. Rev. 29: 525-546.

BARRETT, R., CHAPPELL, C., QUICK, M. and FLEMING, A.(2006). A rapid, high content, in vivo model of glucocorticoid-induced osteoporosis. Biotechnol. J. 1 : 651-655.

BECKER, T., WULLIMANN, M.F., BECKER, C.G., BERNHARDT, R.R. and SCHACHNER, M.(1997). Axonal regrowth after spinal cord transection in adult zebrafish. J. Comp. Neurol. 377: 577-595.

BELMAMOUNE, M. and VERBEEK, F.J. (2006). Heterogeneous information systems: bridging the gap of time and space. pp. 53-58. In: Guerrero-Bote, V. P. (Ed.) Current Research in Information Sciences and Technologies: Multidisciplinary approaches to global information systems.

BELMAMOUNE, M. and VERBEEK, F.J.(2007). Developmental anatomy ontology of zebrafish: an integrative semantic framework. J. Integrative Bioinformatics 4: 65.

BEREITER-HAHN, J. and ZYLBERBERG, L.(1993). Regeneration of teleost fish scale (review). Comp. Biochem. Physiol. 105A: 625-641.

BERGHMANS, S., JETTE, C., LANGENAU, D., HSU, K., STEWART, R., LOOK, T. and KANKI, J.P.(2005). Making waves in cancer research: new models in the zebrafish. BioTechniques 39: 227-237.

BERNHARDT, R.R., TONGIORGI, E., ANZINI, P. and SCHACHNER, M.(1996). Increased expression of specific recognition molecules by retinal ganglion cells and by optic pathway glia accompanies the successful regeneration of retinal axons in adult zebrafish. J. Comp. Neurol. 376: 253-264.

BIER, E. and MCGINNIS, W. (2003). Model organisms in development and disease. In Molecular Basis of Inborn Errors of Development. (Ed. C. J., Erikson, R. P., and Wynshw-Boris A.). Oxford University Press, Epstein.

BIRD, N.C. and MABEE, P.M.(2003). Developmental morphology of the axial skeleton of the zebrafish, Danio rerio(Ostariophysi: Cyprinidae). Dev. Dyn. 228: 337-357.

BOURIN, M. and HASCOET, M.(2003). The mouse light/dark box test. Eur. J. Pharmacol. 463: 55-65.

BRICKELL, P.M. and TICKLE, C.(1989). Morphogens in chick limb development. Bioessays 11: 145-149.

BROCKES, J.P. and KUMAR, A.(2005). Appendage regeneration in adult vertebrates and implications for regenerative medicine. Science 310: 1919-1923.

CLARK, P.M.(1998). Programming of the hypothalamo-pituitary-adrenal axis and the fetal origins of adult disease hypothesis. Eur. J. Pediatr. 157 Suppl 1: S710.

CLAY, H., DAVIS, J.M., BEERY, D., HUTTENLOCHER, A., LYONS, S.E. and RAMAKRISHNAN, L.(2007). Dichotomous role of the macrophage in early Mycobacterium marinuminfection of the zebrafish. Cell. Host. Microbe2: 29-39.

COSMA, C.L., HUMBERT, O. and RAMAKRISHNAN, L.(2004). Superinfecting mycobacteria home to established tuberculous granulomas. Nat. Immunol. 5:
828-835.

COSMA, C.L., KLEIN, K., KIM, R., BEERY, D. and RAMAKRISHNAN, L.(2006) Mycobacterium marinum Erp is a virulence determinant required for cell wall integrity and intracellular survival. Infect. Immun. 74: 3125-3133.

CROTWELL, P.L. and MABEE, P.M.(2007). Gene expression patterns underlying proximal-distal skeletal segmentation in late-stage zebrafish, Danio rerio. Dev. Dyn. 236: 3111-3128.

CROWHURST, M.O., LAYTON, J.E. and LIESCHKE, G.J.(2002). Developmental biology of zebrafish myeloid cells. Int. J. Dev. Biol. 46: 483-492.

DAHM, R. and GEISLER, R.(2006). Learning from small fry: the zebrafish as a genetic model organism for aquaculture fish species. Mar. Biotechnol. (NY) 8 : 329-345.

DAI, K.R., XU, X.L., TANG, T.T., ZHU, Z.A., YU, C.F., LOU, J.R. and ZHANG, X.L.(2005). Repairing of goat tibial bone defects with BMP-2 gene-modified tissue-engineered bone. Calcif. Tissue Int. 77: 55-61.

DANIELS, K., REITER, R. and SOLURSH, M.(1996). Micromass cultures of limb and other mesenchyme. Methods Cell Biol. 51: 237-247.

DAVIDSON, A.J. and ZON, L.I.(2004). The 'definitive' (and 'primitive') guide to zebrafish hematopoiesis. Oncogene 23: 7233-7246.

DAVIS, J.M., CLAY, H., LEWIS, J.L., GHORI, N., HERBOMEL, P. and RAMAKRISHNAN, L.(2002). Real-time visualization of mycobacterium-macrophage interactions leading to initiation of granuloma formation in zebrafish embryos. Immunity. 17: 693-702.

DEL RINCON, S.V. and SCADDING, S.R.(2002). Retinoid antagonists inhibit normal patterning during limb regeneration in the axolotl, Ambystomamexicanum. J. Exp. Zool. 292: 435-443.

DRIEVER, W., SOLNICA-KREZEL, L., SCHIER, A.F., NEUHAUSS, S.C., MALICKI, J., STEMPLE, D.L., STAINIER, D.Y., ZWARTKRUIS, F., ABDELILAH, S., RANGINI, Z., BELAK, J. and BOGGS, C.(1996). A genetic screen for mutations affecting embryogenesis in zebrafish. Development 123: 37-46.

DU, S.J., FRENKEL, V., KINDSCHI, G. and ZOHAR, Y.(2001). Visualizing normal and defective bone development in zebrafish embryos using the fluorescent chromophore calcein. Dev. Biol. 238: 239-246.

EICHELE, G., TICKLE, C. and ALBERTS, B.M.(1984). Microcontrolled release of biologically active compounds in chick embryos: beads of 200-microns diameter for the local release of retinoids. Anal. Biochem. 142: 542-555.

FERRETTI, P. and GÉRAUDIE, J.(1995). Retinoic acid-induced cell death in the wound epidermis of regenerating zebrafish fins. Dev. Dyn. 202: 271-283.

FLEMING, A., SATO, M. and GOLDSMITH, P.(2005). High-throughput in vivo screening for bone anabolic compounds with zebrafish. J. Biomol. Screen. 10: 823-831.

FLIK, G., FENWICK, J.C., KOLAR, Z., MAYER-GOSTAN, N. and WENDELAABONGA, S.E.(1986). Effects of low ambient calcium levels on wholebody ca2+ flux rates and internal calcium pools in the freshwater cichlid teleost, Oreochromis mossambicus. J. Exp. Biol. 120: 249-264.

GAO, L.Y., PAK, M., KISH, R., KAJIHARA, K. and BROWN, E.J.(2006). A mycobacterial operon essential for virulence in vivo and invasion and intracellular persistence in macrophages. Infect. Immun. 74: 1757-1767.

GÉRAUDIE, J., BRULFERT, A., MONNOT, M.J. and FERRETTI, P.(1994). Teratogenic and morphogenetic effects of retinoic acid on the regenerating pectoral fin in zebrafish. J. Exp. Zool. 269: 12-22.

GÉRAUDIE, J., MONNOT, M.J., RIDET, A., THOROGOOD, P. and FERRETTI, P.(1993). Is exogenous retinoic acid necessary to alter positional information during regeneration of the fin in zebrafish? Prog. Clin. Biol. Res. 383B: 803-814.

GERLAI, R.(2003). Zebra fish: an uncharted behavior genetic model. Behav. Genet. 33: 461-468.

GERLAI, R., LAHAV, M., GUO, S. and ROSENTHAL, A.(2000b). Drinks like a fish: zebra fish (Danio rerio) as a behavior genetic model to study alcohol effects. Pharmacol. Biochem. Behav. 67: 773-782.

GERRITSEN, M., KROS, A., SPRAKEL, V., LUTTERMAN, J.A., NOLTE, R.J.M. and JANSEN, J.A.(2000). Biocompatibility evaluation of sol-gel coatings for subcutaneously implantable glucse sensors. Biomaterials 21:71-78. Biomaterials 21: 71-78.

GESCHWIND, D.H. and LEVITT, P.(2007). Autism spectrum disorders: developmental disconnection syndromes. Curr. Opin. Neurobiol. 17: 103-111. 
GIBERT, Y., GAJEWSKI, A., MEYER, A. and BEGEMANN, G.(2006). Induction and prepatterning of the zebrafish pectoral fin bud requires axial retinoic acid signaling. Development 133: 2649-2659.

GILLESPIE, C.F. and NEMEROFF, C.B.(2005). Hypercortisolemia and depression. Psychosom. Med. 67 Suppl 1: S26-S28.

GOODMAN, F.R.(2002). Limb malformations and the human HOX genes. Am. J. Med. Genet. 112: 256-265.

GOODMAN, F.R., MUNDLOS, S., MURAGAKI, Y., DONNAI, D., GIOVANNUCCIUZIELLI, M.L., LAPI, E., MAJEWSKI, F., MCGAUGHRAN, J., MCKEOWN, C., REARDON, W., UPTON, J., WINTER, R.M., OLSEN, B.R. and SCAMBLER, P.J.(1997). Synpolydactyly phenotypes correlate with size of expansions in HOXD13 polyalanine tract. Proc. Natl. Acad. Sci. USA 94: 7458-7463.

GRANDEL, H. and SCHULTE-MERKER, S.(1998). The development of the paired fins in the Zebrafish (Danio rerio). Mech. Dev. 79: 99-120.

GRUNWALD, D.J. and EISEN, J.S.(2002). Headwaters of the zebrafish - emergence of a new model vertebrate. Nat. Rev. Genet. 3: 717-724.

GUNNAR, M.R. and QUEVEDO, K.M.(2008). Early care experiences and HPA axis regulation in children: a mechanism for later trauma vulnerability. Prog. Brain Res. 167: 137-149.

GUO, S.(2004). Linking genes to brain, behavior and neurological diseases: what can we learn from zebrafish? Genes Brain Behav. 3: 63-74.

HABIBOVIC, P., YUAN, H., VAN DEN, D.M., SEES, T.M., VAN BLITTERSWIJK, C.A. and DE GROOT, K.(2006). Relevance of osteoinductive biomaterials in critical-sized orthotopic defect. J Orthop. Res. 24: 867-876.

HAFFTER, P., GRANATO, M., BRAND, M., MULLINS, M.C., HAMMERSCHMIDT, M., KANE, D.A., ODENTHAL, J., VANEEDEN, F.J.M., JIANG, Y.J., HEISENBERG, C.P., KELSH, R.N., FURUTANISEIKI, M., VOGELSANG, E., BEUCHLE, D., SCHACH, U., FABIAN, C. and NUSSLEINVOLHARD, C.(1996). The identification of genes with unique and essential functions in the development of the zebrafish, Danio rerio. Development 123: 1-36.

HALDI, M., TON, C., SENG, W.L. and MCGRATH, P.(2006). Human melanoma cells transplanted into zebrafish proliferate, migrate, produce melanin, form masses and stimulate angiogenesis in zebrafish. Angiogenesis. 9: 139-151.

HALL, C., FLORES, M.V., STORM, T., CROSIER, K. and CROSIER, P.(2007). The zebrafish lysozyme $\mathrm{C}$ promoter drives myeloid-specific expression in transgenic fish. BMC. Dev. Biol. 7: 42.

HENDRICKS, M. and JESUTHASAN, S.(2007). Electroporation-based methods for in vivo, whole mount and primary culture analysis of zebrafish brain development. Neural Develop. 2: 6.

HERBOMEL, P. and LEVRAUD, J.P.(2005). Imaging early macrophage differentiation, migration, and behaviors in live zebrafish embryos. Methods Mol. Med. 105: 199-214.

HERBOMEL, P., THISSE, B. and THISSE, C.(1999). Ontogeny and behaviour of early macrophages in the zebrafish embryo. Development 126: 3735-3745.

HYATT, G.A., SCMITT, E.A., MARSH-ARMSTRONG, N., MCCAFFEREY, P., DRÄGER, U.C. and DOWLING, J.E. (1996). Retinoic acid establishes ventral retinal characteristics. Development 122: 195-204.

KAATTARI, I.M., RHODES, M.W., KAATTARI, S.L. and SHOTTS, E.B.(2006). The evolving story of Mycobacterium tuberculosis "clade members detected in fish. J. Fish. Dis. 29: 509-520.

KARI, G., RODECK, U. and DICKER, A.P.(2007). Zebrafish: an emerging model system for human disease and drug discovery. Clin. Pharmacol. Ther. 82: 7080 .

KASAHARA, M., SUZUKI, T. and PASQUIER, L.D.(2004). On the origins of the adaptive immune system: novel insights from invertebrates and cold-blooded vertebrates. Trends Immunol. 25: 105-111.

KROS, A., GERRITSEN, M., SPRAKEL, V.S.I., SOMMERDIJK, N.A.J.M., JANSEN, J.A. and NOLTE, R.J.M.(2001). Silica-based hybrid materials as biocompatible coatings for glucose sensors. Sens. Actuators, B. 81: 68-75.

KROS, A., JANSEN, J.A., HOLDER, S.J., NOLTE, R.J.M. and SOMMERDIJK, N.A.J.M.(2002). Silane-based hybrids for biomedical applications. J. Adhes. Sci. Technol. 16: 143-155.

KRUYT, M.C., PERSSON, C., JOHANSSON, G., DHERT, W.J. and DE BRUIJN, J.D.(2006). Towards injectable cell-based tissue-engineered bone: the effect of different calcium phosphate microparticles and pre-culturing. Tissue Eng. 12:
309-317.

LEVINE, S.(2005). Developmental determinants of sensitivity and resistance to stress. Psychoneuroendocrinology 30: 939-946.

LEVRAUD, J.P., BOUDINOT, P., COLIN, I., BENMANSOUR, A., PEYRIERAS, N., HERBOMEL, P. and LUTFALLA, G.(2007). Identification of the zebrafish IFN receptor: implications for the origin of the vertebrate IFN system. J. Immunol 178: 4385-4394.

LI, M., FRY, B.G. and KINI, R.M.(2005). Putting the brakes on snake venom evolution: the unique molecular evolutionary patterns of Aipysurus eydouxi (Marbled sea snake) phospholipase A2 toxins. Molec. Biol. Evol. 22: 934-941.

LI, X., WANG, S., QI, J., ECHTENKAMP, S.F., CHATTERJEE, R., WANG, M., BOONS, G.J., DZIARSKI, R. and GUPTA, D.(2007). Zebrafish peptidoglycan recognition proteins are bactericidal amidases essential for defense against bacterial infections. Immunity. 27: 518-529.

LIESCHKE, G.J. and CURRIE, P.D.(2007). Animal models of human disease zebrafish swim into view. Nat. Rev. Genet. 8: 353-367.

LIESCHKE, G.J., OATES, A.C., CROWHURST, M.O., WARD, A.C. and LAYTON, J.E.(2001). Morphologic and functional characterization of granulocytes and macrophages in embryonic and adult zebrafish. Blood 98: 3087-3096.

LOCK, E.J., ORNSRUD, R., AKSNES, L., SPANINGS, F.A., WAAGBO, R. and FLIK, G.(2007). The vitamin D receptor and its ligand 1alpha,25-dihydroxyvitamin D3 in Atlantic salmon (Salmo salar). J. Endocrinol. 193: 459-471.

LUO, Q., KANG, Q., SI, W., JIANG, W., PARK, J.K., PENG, Y., LI, X., LUU, H.H., LUO, J., MONTAG, A.G., HAYDON, R.C. and HE, T.C.(2004). Connective tissue growth factor (CTGF) is regulated by Wnt and bone morphogenetic proteins signaling in osteoblast differentiation of mesenchymal stem cells. $J$ Biol. Chem. 279: 55958-55968.

LUTTRELL, L.M. (2008). Reviews in Molecular Biology and Biotechnology: Transmembrane Signaling by G Protein-Coupled Receptors. Mol. Biotechnol. 39: 239-264.

MADEN, M.(1982). Vitamin A and pattern formation in the regenerating limb. Nature 295: $672-675$.

MARI-BEFFA, M., SANTAMARIA, J.A., MURCIANO, C., SANTOS-RUIZ, L., ANDRADES, J.A., GUERADO, E. and BECERRA, J.(2007). Zebrafish fins as a model system for skeletal human studies. Scientific World Journal. 7: 11141127.

MATHEW, L.K., SENGUPTA, S., KAWAKAMI, A., ANDREASEN, E.A., LOHR, C.V., LOYNES, C.A., RENSHAW, S.A., PETERSON, R.T. and TANGUAY, R.L.(2007). Unraveling tissue regeneration pathways using chemical genetics. J. Biol. Chem. 282: 35202-35210.

MATHIAS, J.R., DODD, M.E., WALTERS, K.B., RHODES, J., KANKI, J.P., LOOK, A.T. and HUTTENLOCHER, A.(2007). Live imaging of chronic inflammation caused by mutation of zebrafish Hai1. J. Cel/ Sci. 120: 3372-3383.

MATHIAS, J.R., PERRIN, B.J., LIU, T.X., KANKI, J., LOOK, A.T. and HUTTENLOCHER, A.(2006). Resolution of inflammation by retrograde chemotaxis of neutrophils in transgenic zebrafish. J. Leukoc. Biol. 80: 1281-1288.

MEIJER, A.H., KRENS, S.F.G., MEDINA RODRIGUEZ, I.A., HE, S., BITTER, W., SNAAR-JAGALSKA, B.E. and SPAINK, H.P.(2004). Expression analysis of the Toll-like receptor and TIR domain adaptor families of zebrafish. Mol /mmunol. 40: 773-783

MEIJER, A.H., VAN DER SAR, A.M., CUNHA, C., LAMERS, G.E., LAPLANTE, M.A., KIKUTA, H., BITTER, W., BECKER, T.S. and SPAINK, H.P.(2008). Identification and real-time imaging of a myc-expressing neutrophil population involved in inflammation and mycobacterial granuloma formation in zebrafish. Dev. Comp. Immunol. 32: 36-49.

MEIJER, A.H., VERBEEK, F.J., SALAS-VIDAL, E., CORREDOR-ADAMEZ, M., BUSSMAN, J., VAN DER SAR, A.M., OTTO, G.W., GEISLER, R. and SPAINK, H.P.(2005). Transcriptome profiling of adult zebrafish at the late stage of chronic tuberculosis due to Mycobacterium marinuminfection. Mol. Immunol. 42: 1185 1203.

MENDES, S.C., TIBBE, J.M., VEENHOF, M., BOTH, S., ONER, F.C., VAN BLITTERSWIJK, C.A. and DE BRUIJN, J.D.(2004). Relation between in vitro and in vivo osteogenic potential of cultured human bone marrow stromal cells. JMater. Sci. Mater. Med. 15: 1123-1128.

MENUDIER, A., ROUGIER, F.P. and BOSGIRAUD, C.(1996). Comparative virulence between different strains of Listeria in zebrafish (Brachydanio rerio) and 
mice. Pathol. Biol. (Paris) 44: 783-789.

MILLER, J.D. and NEELY, M.N.(2005). Large-scale screen highlights the importance of capsule for virulence in the zoonotic pathogen Streptococcus iniae. Infect. Immun. 73: 921-934.

MURAYAMA, E., KISSA, K., ZAPATA, A., MORDELET, E., BRIOLAT, V., LIN, H.F., HANDIN, R.I. and HERBOMEL, P.(2006). Tracing hematopoietic precursor migration to successive hematopoietic organs during zebrafish development. Immunity. 25: 963-975.

NAKATANI, Y., KAWAKAMI, A. and KUDO, A.(2007). Cellular and molecular processes of regeneration, with special emphasis on fish fins. Dev. Growth Differ. 49: 145-154

NEELY, M.N., PFEIFER, J.D. and CAPARON, M.(2002). Streptococcus-zebrafish model of bacterial pathogenesis. Infect. Immun. 70: 3904-3914.

NEWMAN, M., MUSGRAVE, I.F. and LARDELLI, M.(2007). Alzheimer disease: amyloidogenesis, the presenilins and animal models. Biochim. Biophys. Acta 1772: 285-297.

NINKOVIC, J. and BALLY-CUIF, L.(2006). The zebrafish as a model system for assessing the reinforcing properties of drugs of abuse. Methods 39: 262-274.

PAGANI, L.S., JAPEL, C., VAILLANCOURT, T., COTE, S. and TREMBLAY, R.E.(2007). Links between life course trajectories of family dysfunction and anxiety during middle childhood. J. Abnorm. Child Psychol.

PARDO, C.A. and EBERHART, C.G.(2007). The neurobiology of autism. Brain Pathol. 17: 434-447.

PARIANTE, C.M.(2006). The glucocorticoid receptor: part of the solution or part of the problem? J. Psychopharmacol. 20: 79-84.

POLEO, G., BROWN, C.W., LAFOREST, L. and AKIMENKO, M.A.(2001). Cell proliferation and movement during early fin regeneration in zebrafish. Dev. Dyn. 221: 380-390.

POSS, K.D., KEATING, M.T. and NECHIPORUK, A.(2003). Tales of regeneration in zebrafish. Dev. Dyn. 226: 202-210.

POSS, K.D., WILSON, L.G. and KEATING, M.T.(2002). Heart regeneration in zebrafish. Science 298: 2188-2190.

PRESSleY, M.E., PHELAN, P.E., III, WITTEN, P.E., MELLON, M.T. and KIM, C.H.(2005). Pathogenesis and inflammatory response to Edwardsiella tarda infection in the zebrafish. Dev. Comp Immunol. 29: 501-513.

PRINCE, V.E. and PICKETT, F.B.(2002). Splitting pairs: The diverging fates of duplicated genes. Nat. Rev. Genet. 3: 827-837.

PROUTY, M.G., CORREA, N.E., BARKER, L.P., JAGADEESWARAN, P. and KLOSE, K.E.(2003). Zebrafish-Mycobacterium marinum model for mycobacterial pathogenesis. FEMS Microbiol. Lett. 225: 177-182.

PRUT, L. and BELZUNG, C.(2003). The open field as a paradigm to measure the effects of drugs on anxiety-like behaviors: a review. Eur. J. Pharmacol. 463: 333.

PRYCE, C.R., RUEDI-BETTSCHEN, D., DETTLING, A.C., WESTON, A., RUSSIG, H., FERGER, B. and FELDON, J.(2005). Long-term effects of early-life environmental manipulations in rodents and primates: Potential animal models in depression research. Neurosci. Biobehav. Rev. 29: 649-674.

PU, X.C., WONG, P.T. and GOPALAKRISHNAKONE, P.(1995). A novel analgesic toxin (hannalgesin) from the venom of king cobra (Ophiophagus hannah). Toxicon 33: 1425-1431.

REDD, M.J., KELLY, G., DUNN, G., WAY, M. and MARTIN, P.(2006). Imaging macrophage chemotaxis in vivo: studies of microtubule function in zebrafish wound inflammation. Cell Motil. Cytoskeleton 63: 415-422.

REDDI, A.H.(2000). Morphogenesis and tissue engineering of bone and cartilage: inductive signals, stem cells, and biomimetic biomaterials. Tissue Eng 6: 351 359.

REIFERS, F., WALSH, E.C., LÉGER, S., STANIER, D.Y. and BRAND, M. (2000). Induction and differentiation of the zebrafish heart requires fibroblast growth factor 8 (fgf8/acerebellar). Development 127: 225-235.

REIM, G. and BRAND, M. (2002). spiel-ohne-grenzen/pou2 mediates regional competence to respond to Fgf8 during zebrafish early neural development. Development 129: 917-933.

RENN, J., WINKLER, C., SCHARTL, M., FISCHER, R. and GOERLICH, R.(2006). Zebrafish and medaka as models for bone research including implications regarding space-related issues. Protoplasma 229: 209-214.
RENSHAW, S.A., LOYNES, C.A., TRUSHELL, D.M., ELWORTHY, S., INGHAM, P.W. and WHYTE, M.K.(2006). A transgenic zebrafish model of neutrophilic inflammation. Blood 108: 3976-3978.

RICHARDSON, M.K. and VERBEEK, F.J.(2003). New directions in comparative embryology and the nature of developmental characters. Animal Biology 53: 303-311.

RUBINSTEIN, A.L.(2003). Zebrafish: from disease modeling to drug discovery. Curr. Opin. Drug Discov. Devel. 6: 218-223.

RUTTER, M., MOFFITT, T.E. and CASPI, A.(2006). Gene-environment interplay and psychopathology: multiple varieties but real effects. J. Child Psychol. Psychiatry 47: 226-261.

SCADDING, S.R.(1988). Treatment of brachial nerves with colchicine inhibits limb regeneration in the newt Notophthalmus viridescens. J. Exp. Zool. 247: 56-61.

SCHAAF, M.J., CHAMPAGNE, D., VAN, L., I, VAN, W., MEIJER, A.H., MEIJER, O.C., SPAINK, H.P. and RICHARDSON, M.K. (2008). Discovery of a functional glucocorticoid receptor $\beta$-isoform in zebrafish. Endocrinology 149: 1591-1599.

SCHERZ, P.J., MCGLINN, E., NISSIM, S. and TABIN, C.J.(2007). Extended exposure to Sonic hedgehog is required for patterning the posterior digits of the vertebrate limb. Dev. Biol. 308: 343-354.

SCHORPP, M., BIALECKI, M., DIEKHOFF, D., WALDERICH, B., ODENTHAL, J., MAISCHEIN, H.M., ZAPATA, A.G. and BOEHM, T.(2006). Conserved functions of Ikaros in vertebrate lymphocyte development: genetic evidence for distinct larval and adult phases of T cell development and two lineages of B cells in zebrafish. J. Immunol. 177: 2463-2476.

SECKL, J.R.(2004). Prenatal glucocorticoids and long-term programming. Eur. J. Endocrinol. 151 Suppl 3: U49-U62.

SILVA, E.A. and MOONEY, D.J.(2004). Synthetic extracellular matrices for tissue engineering and regeneration. Curr. Top. Dev. Biol. 64: 181-205.

SIMON, H.G. and TABIN, C.J.(1993). Analysis of Hox-4.5 and Hox-3.6 expression during newt limb regeneration: differential regulation of paralogous Hox genes suggest different roles for members of different Hox clusters. Development117: 1397-1407.

STERN, H.M. and ZON, L.I.(2003). Cancer genetics and drug discovery in the zebrafish. Nat. Rev. Cancer 3: 533-539.

STOCKHAMMER, O.W., ZAKRZEWSKA, A., HEGEDÛS, Z., SPAINK, H.P. and MEIJER, A.H. (2009). Transcriptome profiling and functional analyses of the zebrafish embryonic innate immune response to Salmonella infection. J/mmunol. 182: $5641-53$.

STOCUM, D.L.(1996). A conceptual framework for analyzing axial patterning in regenerating urodele limbs. Int. J. Dev. Biol. 40: 773-783.

STOLTE, E.H., VAN KEMENADE, B.M., SAVELKOUL, H.F. and FLIK, G.(2006). Evolution of glucocorticoid receptors with different glucocorticoid sensitivity. J. Endocrinol. 190: 17-28.

THUMMEL, R., BAI, S., SARRAS, M.P., JR., SONG, P., MCDERMOTT, J., BREWER, J., PERRY, M., ZHANG, X., HYDE, D.R. and GODWIN, A.R.(2006). Inhibition of zebrafish fin regeneration using in vivo electroporation of morpholinos against fgfr1 and msxb. Dev. Dyn. 235: 336-346.

TICKLE, C., ALBERTS, B., WOLPERT, L. and LEE, J.(1982). Local application of retinoic acid to the limb bond mimics the action of the polarizing region. Nature 296: 564-566.

TREDE, N.S., LANGENAU, D.M., TRAVER, D., LOOK, A.T. and ZON, L.I.(2004). The use of zebrafish to understand immunity. Immunity. 20: 367-379.

TROPEPE, V. and SIVE, H.L.(2003). Can zebrafish be used as a model to study the neurodevelopmental causes of autism? Genes Brain Behav. 2: 268-281.

VAN BEZOOIJEN, R.L., ROELEN, B.A., VISSER, A., WEE-PALS, L., DE WILT, E., KARPERIEN, M., HAMERSMA, H., PAPAPOULOS, S.E., TEN DIJKE, P. and LOWIK, C.W.(2004). Sclerostin is an osteocyte-expressed negative regulator of bone formation, but not a classical BMP antagonist. J. Exp. Med. 199: 805-814.

VAN DER SAR, A.M., ABDALLAH, A.M., SPARRIUS, M., REINDERS, E., VANDENBROUCKE-GRAULS, C.M. and BITTER, W.(2004). Mycobacterium marinumstrains can be divided into two distinct types based on genetic diversity and virulence. Infect. Immun. 72: 6306-6312.

VAN DER SAR, A.M., MUSTERS, R.J., VAN EEDEN, F.J., APPELMELK, B.J., VANDENBROUCKE-GRAULS, C.M. and BITTER, W.(2003). Zebrafish embryos as a model host for the real time analysis of Salmonella typhimurium 
infections. Cell Microbiol. 5: 601-611.

VAN DER SAR, A.M., STOCKHAMMER, O.W., VAN DER, L.C., SPAINK, H.P., BITTER, W. and MEIJER, A.H.(2006). MyD88 innate immune function in a zebrafish embryo infection model. Infect. Immun. 74: 2436-2441.

VEGA, R.B., MATSUDA, K., OH, J., BARBOSA, A.C., YANG, X., MEADOWS, E., MCANALLY, J., POMAJZL, C., SHELTON, J.M., RICHARDSON, J.A., KARSENTY, G. and OLSON, E.N.(2004). Histone deacetylase 4 controls chondrocyte hypertrophy during skeletogenesis. Cel/119: 555-566.

VERBEEK, F.J. and BOON, P.J. (2002). High Resolution 3D Reconstruction from serial sections: microscope instrumentation, software design and its implementations. Proceedings of SPIE (The International Society of Optical Engineering) 4621 (in press).

VERBEEK, F.J., BOON, P.J., SLOETJES, H., VAN DER VELDE, R. and DE VOS, N.(2002). Visualization of complex data sets over Internet: 2D and 3D visualization of the 3D digital atlas of zebrafish development. Proceedings of SPIE (The International Society of Optical Engineering) 4672: 20-29.

VERBEEK, F.J., DEN BRODER, M.J., BOON, P.J., BUITENDIJK, B., DOERRY, E., VAN RAAIJ, E.J. and ZIVKOVIC, D. (2000). A standard atlas of zebrafish embryonic development for projection of experimental data. Proceedings of SPIE (The International Society of Optical Engineering) 242-252.

VOLKMAN, H.E., CLAY, H., BEERY, D., CHANG, J.C., SHERMAN, D.R. and RAMAKRISHNAN, L. (2004). Tuberculous granuloma formation is enhanced by a mycobacterium virulence determinant. PLOS. Biol. 2: e367.

VON DER HARDT, S., BEKKERS, J., INBAL, A., CARVALHO, L., SOLNICAKREZEL, L., HEISENBERG, C.-P. and HAMMERSCHMIDT, M. (2007). The Bmp gradient of the zebrafish gastrula guides migrating lateral cells by regulating cell-cell adhesion. Curr. Biol. 17: 475-487.

WANG, W., LIU, X., GELINAS, D., CIRUNA, B. and SUN, Y.(2007). A fully automated robotic system for microinjection of zebrafish embryos. PLOS. ONE. 2: e862.

WELTEN, M.C.M., DE HAAN, S., VAN DEN BOOGERT, N., NOORDEMEER, J.N., LAMERS, G., SPAINK, H.P., MEIJER, A.H. and VERBEEK, F.J.(2006). ZebraFISH: Fluorescent in situ hybridization protocol and 3D images of gene expression patterns. Zebrafish 3: 465-476.

WENDELAAR BONGA, S.E.(1997). The stress response in fish. Physiol Rev. 77:
591-625.

WHITE, J.A., BOFFA, M.B., JONES, B. and PETKOVICH, M.(1994). A zebrafish retinoic acid receptor expressed in the regenerating caudal fin. Development 120: $1861-1872$.

WIENHOLDS, E. and PLASTERK, R.H.(2004). Target-selected gene inactivation in zebrafish. Methods Cell Biol. 77: 69-90.

WIENHOLDS, E., SCHULTE-MERKER, S., WALDERICH, B. and PLASTERK, R.H.(2002). Target-selected inactivation of the zebrafish rag1 gene. Science 297: 99-102

WIENHOLDS, E., VAN EEDEN, F., KOSTERS, M., MUDDE, J., PLASTERK, R.H. and CUPPEN, E.(2003). Efficient target-selected mutagenesis in zebrafish. Genome Res. 13: 2700-2707.

YAMAMOTO, M., TAKAHASHI, Y. and TABATA, Y.(2006). Enhanced bone regeneration at a segmental bone defect by controlled release of bone morphogenetic protein-2 from a biodegradable hydrogel. Tissue Eng. 12: 1305-1311.

YOKOGAWA, T., MARIN, W., FARACO, J., PEZERON, G., APPELBAUM, L., ZHANG, J., ROSA, F., MOURRAIN, P. and MIGNOT, E.(2007). Characterization of sleep in zebrafish and insomnia in hypocretin receptor mutants. PLOS. Biol. 5: 2379-2397.

YOSHIKUBO, H., SUZUKI, N., TAKEMURA, K., HOSO, M., YASHIMA, S., IWAMURO, S., TAKAGI, Y., TABATA, M.J. and HATTORI, A.(2005). Osteoblastic activity and estrogenic response in the regenerating scale of goldfish, a good model of osteogenesis. Life Sci. 76: 2699-2709.

YUAN, H., VANBLITTERSWIJK, C.A., DE GROOT, K. and DE BRUIJN, J.D.(2006a). A comparison of bone formation in biphasic calcium phosphate (BCP) and hydroxyapatite (HA) implanted in muscle and bone of dogs at different time periods. J Biomed. Mater. Res. A 78: 139-147.

YUAN, H., VANBLITTERSWIJK, C.A., DE GROOT, K. and DE BRUIJN, J.D.(2006b). Cross-species comparison of ectopic bone formation in biphasic calcium phosphate (BCP) and hydroxyapatite (HA) scaffolds. Tissue Eng. 12: 16071615.

YUII, K., SUZUKI, M. and KURACHI, M.(2007). Stress sensitization in schizophrenia. Ann. N. Y. Acad. Sci. 1113: 276-290.

ZON, L.I. and PETERSON, R.T.(2005). In vivodrug discovery in the zebrafish. Nat. Rev. Drug Discov. 4: 35-44.

\section{For all the latest on Pattern Formation research, see our latest Special Issue edited by C.-M. Chuong and M.K. Richardson.}

http://www.ijdb.ehu.es/web/contents.php?vol=53\&issue=5-6
5 yr ISI Impact Factor $(2008)=3.271$

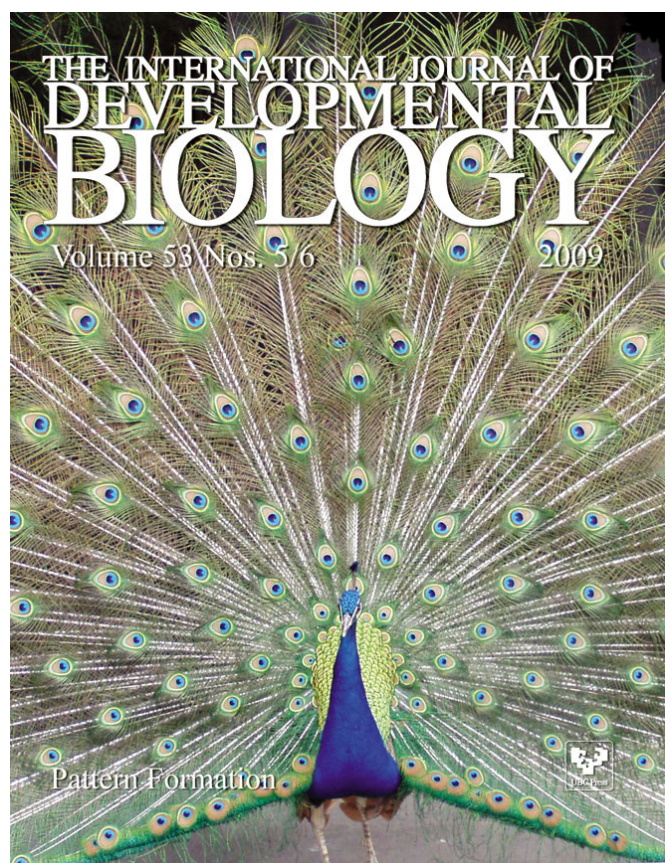




\section{Further Related Reading, published previously in the Int. J. Dev. Biol.}

See our Special Issue Developmental Morphodynamics edited by Lev Beloussov and Richard Gordon at:

http://www.ijdb.ehu.es/web/contents.php?vol=50\&issue=2-3

See our Special Issue Fertilization, in honor of David L. Garbers and edited by Paul M. Wassarman and Victor D. Vacquier at: http://www.ijdb.ehu.es/web/contents.php?vol=52\&issue=5-6

Eye development at the Houston "Fly Meeting"

Amit Singh

Int. J. Dev. Biol. (2006) 50: 659-663

Transient expression of apoaequorin in zebrafish embryos: extending the ability to image calcium transients during later stages of development

Chris Y. Cheung, Sarah E. Webb, Anming Meng and Andrew L. Miller

Int. J. Dev. Biol. (2006) 50: 561-569 [Abstract] [FullText Open Access]

Genetics of photoreceptor development and function in zebrafish

Motokazu Tsujikawa and Jarema Malicki

Int. J. Dev. Biol. (2004) 48: 925-934

The "chemoinvasion assay": a tool to study tumor and endothelial cell invasion of basement membranes

Adriana Albini, Roberto Benelli, Douglas M. Noonan and Claudio Brigati

Int. J. Dev. Biol. (2004) 48: 563-571

Tumor invasion and metastasis: getting more basic to come closer to the patient. An interview with Lance A. Liotta.

Vincent Castronovo

Int. J. Dev. Biol. (2004) 48: 559-562

Developmental biology of zebrafish myeloid cells.

Meredith O Crowhurst, Judith E Layton and Graham J Lieschke

Int. J. Dev. Biol. (2002) 46: 483-492

Chitin oligosaccharides as candidate patterning agents in zebrafish embryogenesis.

C E Semino and M L Allende

Int. J. Dev. Biol. (2000) 44: 183-193

Differential expression of FGF receptors during zebrafish fin regeneration

L Santos-Ruiz, JA Santamaria, J Becerra

Int. J. Dev. Biol. (2001) 45: S131-S132

Zebrafish keratin 8 is expressed at high levels in the epidermis of regenerating caudal fin. M L Martorana, M Tawk, T Lapointe, N Barre, M Imboden, C Joulie, J Géraudie and S Vriz Int. J. Dev. Biol. (2001) 45: 449-452

Expression of two even-skipped genes eve1 and evx2 during zebrafish fin morphogenesis and their regulation by retinoic acid.

A Brulfert, M J Monnot and J Géraudie

Int. J. Dev. Biol. (1998) 42: 1117-1124

Caudal fin regeneration in wild type and long-fin mutant zebrafish is affected by retinoic acid.

J Géraudie, M J Monnot, A Brulfert and P Ferretti

Int. J. Dev. Biol. (1995) 39: 373-381

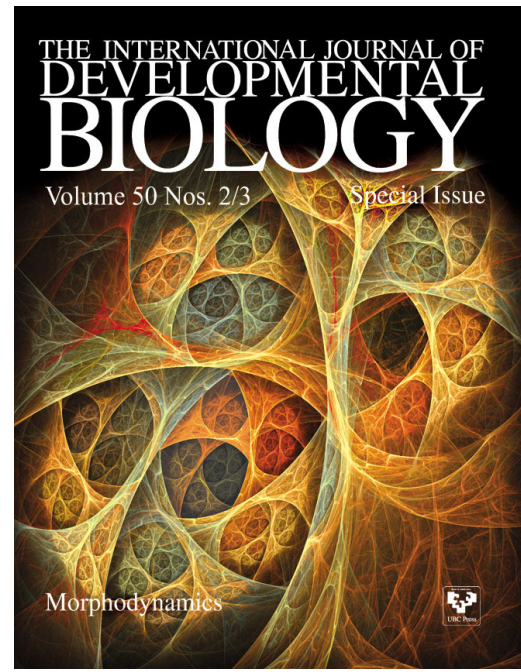

5 yr ISI Impact Factor $(2008)=3.271$

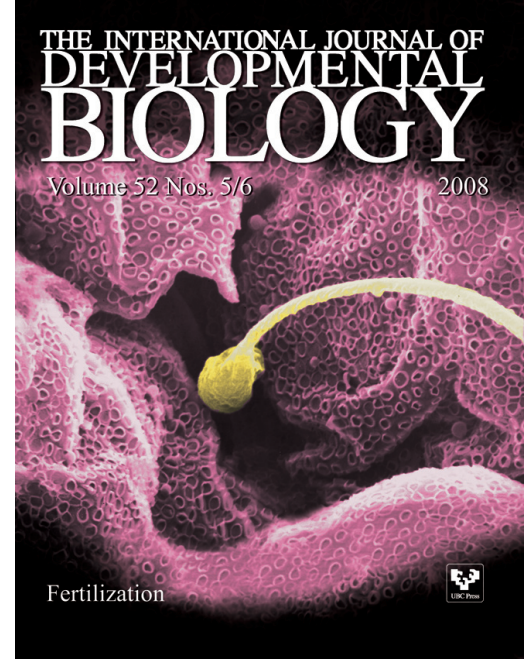

